NIST Special Publication 1178

\title{
Impact of More Precise Construction Data on Estimated Savings from Energy Standard Adoption for Commercial Buildings
}

Joshua Kneifel

David Butry

This publication is available free of charge from:

http://dx.doi.org/10.6028/NIST.SP.1178
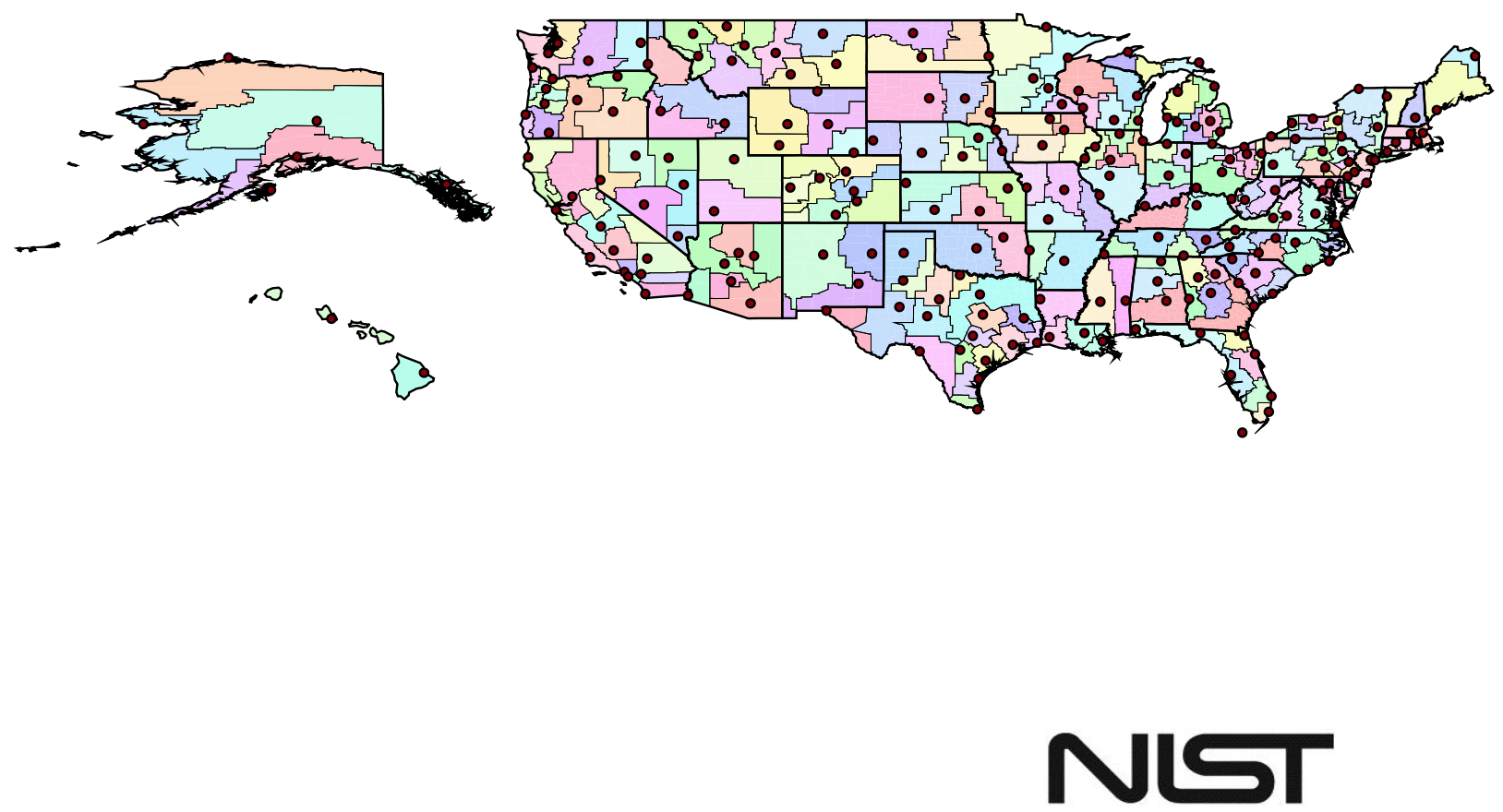

National Institute of Standards and Technology U.S. Department of Commerce 

NIST Special Publication 1178

\title{
Impact of More Precise Construction Data on Estimated Savings from Energy Standard Adoption for Commercial Buildings
}

\author{
Joshua Kneifel \\ David Butry \\ Applied Economics Office \\ Engineering Laboratory
}

This publication is available free of charge from:

http://dx.doi.org/10.6028/NIST.SP.1178

December 2014

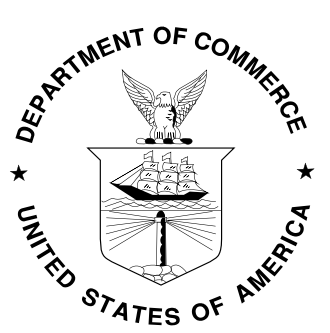

U.S. Department of Commerce

Penny Pritzker, Secretary

National Institute of Standards and Technology 
Certain commercial entities, equipment, or materials may be identified in this document in order to describe an experimental procedure or concept adequately. Such identification is not intended to imply recommendation or endorsement by the National Institute of Standards and Technology, nor is it intended to imply that the entities, materials, or equipment are necessarily the best available for the purpose.

National Institute of Standards and Technology Special Publication 1178

Natl. Inst. Stand. Technol. Spec. Pub. 1178, 43 pages (December 2014) CODEN: NTNOEF

This publication is available free of charge from: http://dx.doi.org/10.6028/NIST.SP.1178 


\begin{abstract}
The Applied Economics Office (AEO) of the Engineering Laboratory (EL) at the National Institute of Standards and Technology (NIST) has developed the Building Industry Reporting and Design for Sustainability (BIRDS) database, which estimates the sustainability (energy, economic, and environmental) performance for eleven commercial building prototypes designed to different energy efficiency levels. Analysis of the BIRDS database estimates both the average percentage change in energy consumption and the aggregate changes in energy consumption for one year's worth of new construction for each U.S. state. Due to the limited publically-available new construction data, the estimates are calculated by giving equal weighting to all the cities in a state that are included in the BIRDS database. However, such an approach leads to underweighting the importance of cities with more new construction and overweighting cities with less new construction.

The purpose of this study is to explore the impact of implementing a non-equal weighting approach on state-level energy consumption impacts of adopting a more restrictive state energy code. New construction floor area completion data for 2012 was obtained for each county in the United States to assist in increasing the accuracy of these impact estimates.
\end{abstract}

\title{
Keywords
}

commercial buildings; whole building energy simulation; energy efficiency; new construction data; geospatial mapping 


\section{Preface}

This study was conducted by the Applied Economics Office (AEO) in the Engineering Laboratory (EL) at the National Institute of Standards and Technology (NIST). The study is designed to compare the sensitivity of estimated savings from energy standard adoption to the precision of the construction data. The intended audience includes researchers in the building sector concerned with energy performance in buildings.

\section{Disclaimers}

The policy of the National Institute of Standards and Technology is to use metric units in all of its published materials. Because this report is intended for the U.S. construction industry that uses U.S. customary units, it is more practical and less confusing to include U.S. customary units in addition to metric units. Measurement values in this report are therefore stated in metric units first, followed by the corresponding values in U.S. customary units within parentheses. 


\section{Acknowledgements}

The author wishes to thank everyone for their advice and recommendations for the writing of this report, including Dr. Eric O'Rear and Dr. Robert Chapman of EL's Applied Economics Office, Matthew Boyd of EL's Energy and Environment Division, and Dr. Nicos S. Martys of EL's Materials and Structural Systems Division.

\section{Author Information}

Joshua D. Kneifel

Economist

National Institute of Standards and Technology

100 Bureau Drive, Mailstop 8603

Gaithersburg, MD 20899-8603

Tel.: 301-975-6857

Email: joshua.kneifel@nist.gov

David Butry

Economist

National Institute of Standards and Technology

100 Bureau Drive, Mailstop 8603

Gaithersburg, MD 20899-8603

Tel.: 301-975-6136

Email: david.butry@nist.gov 


\section{Contents}

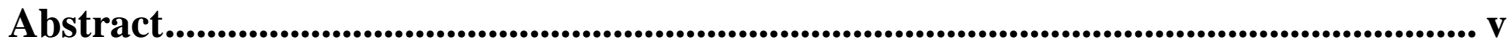

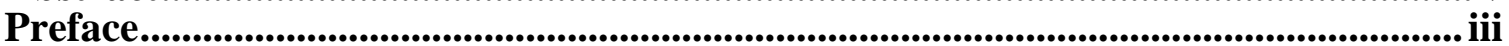

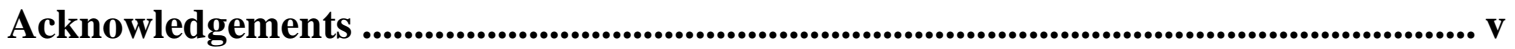

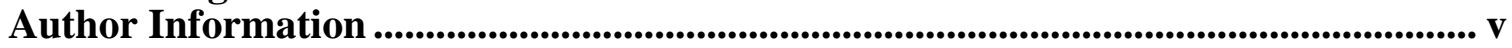

List of Acronyms .............................................................................................................. xi

1 Introduction .................................................................................................................... 1

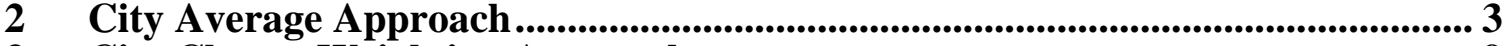

3 City Cluster Weighting Approach.........................................................................99

4 Energy Consumption Savings Comparison............................................................... 13

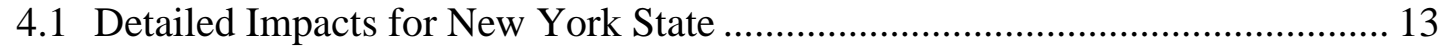

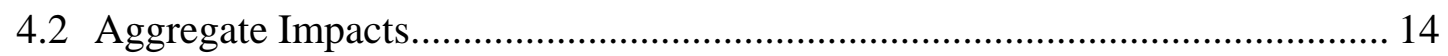

5 Discussion, Limitations, and Future Research................................................ 17

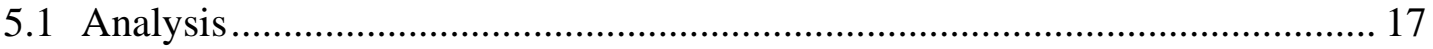

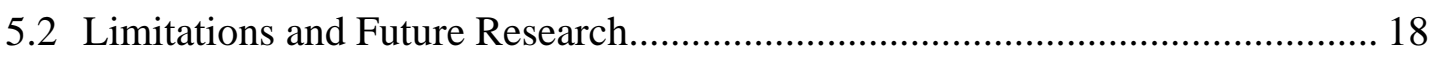

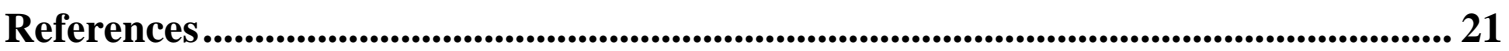

A Building Type, New Construction, and Energy Savings ....................................... 23 


\section{List of Figures}

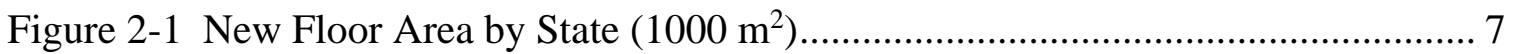

Figure 2-2 Total 10-Year Energy Use Savings by State $(\mathrm{GWh})$.................................. 7

Figure 3-1 Cities and Associated (Colored) County Clusters ......................................... 9

Figure 3-2 New Floor Area by State and County Cluster............................................ 12

Figure 4-1 New Floor Area by City Cluster for New York........................................... 13

Figure 4-2 Difference between Energy Savings using the City Cluster Approach relative

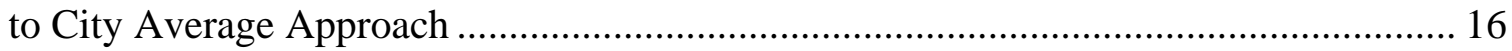

Figure 5-1 City Clusters - Kentucky and Surrounding States..................................... 18

\section{List of Tables}

Table 2-1 New Commercial Building Construction (U.S., 2003 through 2007) ............... 6

Table 3-1 Crosswalk between BIRDS buildings and McGraw-Hill Dodge Construction

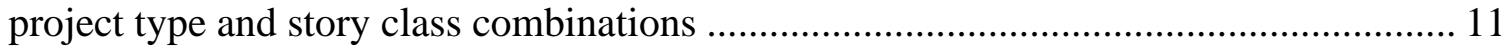

Table 4-1 Change in Energy Consumption by Weighting Approach and Building Type -

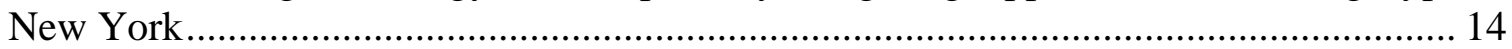

Table 4-2 Change in State Energy Consumption (GWh) by Weighting Approach......... 15

Table A-1 CBECS Categories and Subcategories .................................................... 23

Table A-2 New Commercial Building Construction Volume for 2003 through 2007 by

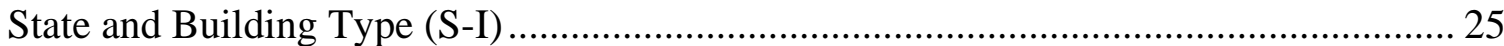

Table A-3 New Commercial Building Construction Volume for 2003 through 2007 by

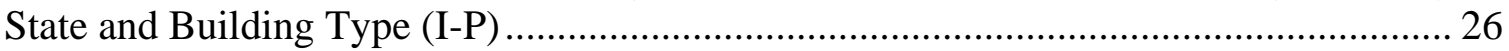

Table A-4 New Commercial Building Construction Share by State and Building Type 27

Table A-5 Energy Consumption Savings by State ................................................... 28 


\section{List of Acronyms}

\section{Acronym Definition}

AEO Applied Economics Office

ASHRAE American Society of Heating, Refrigerating and Air-Conditioning Engineers

BIRDS Building Industry Reporting and Design for Sustainability

CBECS Commercial Buildings Energy Consumption Survey

EL Engineering Laboratory

NIST National Institute of Standards and Technology 


\section{Introduction}

Energy efficiency requirements in current energy codes for commercial buildings vary across states, and many states have not yet adopted the latest editions of American Society of Heating, Refrigerating and Air-Conditioning Engineers (ASHRAE) Standard 90.1, which is the industry consensus standard to establish the minimum energy-efficient requirements of commercial and non-low-rise residential buildings. Some states do not have a code requirement for energy efficiency, leaving it up to the locality or jurisdiction to set its own requirement. There may be significant energy savings to be realized by states if they were to adopt more recent editions of the commercial building energy standards.

The Applied Economics Office (AEO) of the Engineering Laboratory (EL) at the National Institute of Standards and Technology (NIST) has developed the Building Industry Reporting and Design for Sustainability (BIRDS) database, which estimates the sustainability (energy, economic, and environmental) performance for eleven commercial building prototypes designed to different energy efficiency levels. ${ }^{1}$ The analysis in Kneifel (2013a, 2013b, 2013c, 2013d, 2013e) uses the BIRDS database to estimate both the average percentage change in energy consumption and the aggregate changes in energy consumption for one year's worth of construction for each U.S. state. Due to the limited publically-available new construction data, the estimates are calculated by giving equal weighting to all the cities in a state that are included in the BIRDS database. However, such an approach leads to underweighting the importance of cities with more new construction and overweighting cities with less new construction.

The purpose of this study is to explore the impact of implementing a non-equal weighting approach on state-level energy consumption impacts of adopting a more restrictive state energy code. New construction floor area completion data from 1970 to 2012 was obtained from McGraw-Hill Dodge Construction database (2013) for each county in the United States to assist in increasing the accuracy of these impact estimates. Each county is associated with one of the 228 cities in the BIRDS database, creating a "cluster" of counties that use the average performance of each building type for the associated city to estimate the impacts of adopting a more stringent state energy code.

\footnotetext{
${ }^{1}$ For details on the design of the BIRDS database, see Kneifel (2011) and Kneifel (2012).
} 


\section{City Average Approach}

The calculations used in previous analyses of the BIRDS database were twofold: (1) average percentage change in annual energy consumption in a state and by building in a state and (2) aggregate change in annual energy consumption in a state. They were calculated using a city average approach, detailed below.

The average percentage change in annual energy consumption in a state is estimated using what will we have defined as the city average approach (CAA) as:

(1) $E_{P C T, j}^{C A A}=\frac{\sum_{i \in B}^{I_{p}} \frac{\sum_{k}^{K_{j}} E_{P C T, i j k}}{K_{j}}}{I_{p}}$

where $E_{P c t, j} \quad=$ weighted-average percentage change in energy consumption for state $j$,

$E_{P c t, j i k}=$ percentage change in energy consumption for city $k$ for building type $i$ for state $j$,

$I_{p} \quad=$ number of prototype building types,

$B \quad=$ set of prototype building types, and

$K_{j} \quad=$ number of cities in state $j$.

The percentage change in annual energy consumption in a state $\left(E_{P C T, j}^{C A A}\right)$ is calculated in two steps. First, calculate the average percentage change across all cities $K$ in a state for building type $i\left(E_{P C T, i j}=\frac{\sum_{k}^{K_{j}} E_{P C T, i j k}}{K_{j}}\right)$. Second, calculate the average of those average changes for all building prototypes in the state $\left(\frac{\sum_{i \in B}^{I} E_{P C T, i j}}{I_{p}}\right)$. The approach results in equal weighting across cities and building types.

This is mathematically equivalent to the following, which is the calculation implemented to calculate the results and allows for direct comparisons across approaches:

(2) $E_{P C T, j}^{C A A}=W_{1, j}^{C A A} * \sum_{i \in B}^{I_{p}} \sum_{k}^{K_{j}} E_{P C T, i j k}$, and

(3) $W_{1, j}^{C A A}=\frac{1}{K_{j} I_{p}}$

The approach leads to equal weighting for each city and building type.

The average percentage change in annual energy consumption in a state by building type is estimated using the city average approach as:

(4) $E_{P C T, i j}^{C A A}=W_{2, j}^{C A A} * \sum_{k}^{K_{j}} E_{P C T, i j k}$, and 
(5) $W_{2, j}^{C A A}=\frac{1}{K_{j}}$.

Again, an equal weighting structure results.

The aggregate change in annual energy consumption in a state is estimated using the city average approach as:

(6) $E_{C F A, j}^{C A A}=\frac{\sum_{i \in B}^{I_{p}} C F A_{i j}{ }^{*} \frac{\sum_{k}^{K_{j}} E_{E F A, i j k}}{K_{j}}}{\frac{\sum_{i \in B}^{I_{p} C F A_{i j}}}{\sum_{i}^{I} C F A_{i j}}}$,

where $E_{C F A, j}=$ total change in energy consumption for state $j$,

$C F A_{i j}=$ newly constructed floor area for building type $i$ for state $j$ in 2012,

$E_{C F A, i j k}=$ change in energy consumption per unit of floor area for city $k$ for building type $i$ for state $j$,

$I \quad=$ number of (all) building types, and

$I_{p} \quad=$ number of prototype building types.

The aggregate change in annual energy consumption in a state $\left(E_{C F A, j}^{C A A}\right)$ is calculated in three steps. First, calculate the average change per unit of floor area across all cities $K$ in a state for building type $i\left(E_{C F A, i j}=\frac{\sum_{k}^{K_{j}} E_{C F A, i j k}}{K_{j}}\right)$. Second, calculate the aggregate change for building type $i\left(E_{C F A, i j}^{C A A}\right)$ in the state by multiplying the change per unit of floor area $\left(E_{C F A, i j}\right)$ by the amount of new floor area for building type $i$ in the state $\left(C F A_{i j}\right)$. Third, sum the aggregate changes for all prototype building types $I_{p}\left(\sum_{i \in B}^{I_{p}} E_{C F A, i j}^{C A A}\right)$ and divide by the fraction of statewide newly constructed floor area represented by the prototype buildings $\left(\frac{\sum_{i \in B}^{I_{p}} C F A_{i j}}{\sum_{i}^{I} C F A_{i j}}\right)$. This final adjustment is to account for the new floor area not accounted for by the prototype buildings in the database. ${ }^{2}$

This is mathematically equivalent to the following:

(7) $E_{C F A, j}^{C A A}=\sum_{i \in B}^{I_{p}} W_{3, i j}^{C A A} \sum_{k}^{K_{j}} E_{C F A, i j k}$,

(8) $W_{3, i j}^{C A A}=\frac{C F A_{i j}}{K_{j} \frac{\sum_{i \in \in}^{I} C F A_{i j}}{\sum_{i}^{I} C F A_{i j}}}$,

${ }^{2}$ A key assumption is that the impacts for the building prototypes included in the BIRDS database are representative of all new construction in a state. 
The aggregate change in annual energy consumption in a state by building type is estimated using the city average approach as:

(9) $E_{C F A, i j}^{C A A}=W_{4, i j}^{C A A} \sum_{k}^{K_{j}} E_{C F A, i j k}$,

(10) $W_{4, j}^{C A A}=\frac{C F A_{i j}}{K_{j}}$.

As is shown in Formula (6), the aggregate approach, implemented in previous analyses of the BIRDS database, estimates energy consumption savings that result from adoption of more stringent state energy codes. This approach uses new construction data aggregated at the state level. Jarnagin and Bandyopadhyay (2010) use the Commercial Buildings Energy Consumption Survey (CBECS) and McGraw-Hill Dodge Construction data on new commercial building construction by building type within a state. The Commercial Buildings Energy Consumption Survey (CBECS) is a sample survey that collects information on the existing stock of U.S. commercial buildings. The sample includes 5215 buildings across the U.S. in 14 building type categories, as shown in Table A-1. These categories include: education, food sales, food service, health care, lodging, mercantile, office, public assembly, public order and safety, religious worship, service, warehouse and storage, other, and vacant. The survey data do not report the age or specific location of the building to protect the confidentiality of the respondents. The McGraw-Hill dataset includes data for all new commercial buildings and additions, with over 254000 records and 761.8 million $\mathrm{m}^{2}$ (8.2 billion $\mathrm{ft}^{2}$ ) of new construction, for 2003 through 2007. The data are more detailed than the CBECS data, and includes year of construction and location.

Jarnagin and Bandyopadhyay (2010) map the more detailed McGraw-Hill dataset to the CBECS categories and subcategories shown in Table 2-1. The prototype commercial buildings analyzed in this study, shown in bold, represent $46.4 \%$ of nationwide new commercial building stock square footage for 2003 through 2007. However, for this study a prototype building is assumed to represent its entire CBECS category (e.g. secondary school also represents primary school), which implies the prototypes together represent $56.8 \%$ of the new commercial building stock for 2003 through 2007. 
Table 2-1 New Commercial Building Construction (U.S., 2003 through 2007)

\begin{tabular}{|c|c|c|c|c|}
\hline Building & Detail & $\begin{array}{c}\text { Conditioned Floor } \\
\text { Area } \\
1000 \mathrm{~m}^{2}\left(1000 \mathrm{ft}^{2}\right)\end{array}$ & $\begin{array}{l}\text { Percentage in } \\
\text { Category }\end{array}$ & $\begin{array}{c}\text { Percentage } \\
\text { of Total }\end{array}$ \\
\hline Office & Large & $20451(220134)$ & $22.2 \%$ & $2.6 \%$ \\
\hline Office & Medium & $37170(400091)$ & $40.4 \%$ & $4.8 \%$ \\
\hline Office & Small & 34468 (371 009) & $37.4 \%$ & $4.5 \%$ \\
\hline Retail & & 93762 (1 009246$)$ & & $12.2 \%$ \\
\hline Strip Mall & & 34847 (375 093) & & $4.5 \%$ \\
\hline School & Primary & 30697 (330 418) & & $4.0 \%$ \\
\hline School & Secondary & $63686(685508)$ & & $8.3 \%$ \\
\hline Hospital & & 21194 (228 131) & & $2.8 \%$ \\
\hline Other Health Care & & 26865 (289 171) & & $3.5 \%$ \\
\hline Restaurant & Sit Down & $4055(43650)$ & & $0.5 \%$ \\
\hline Restaurant & Fast Food & 3605 (38 809) & & $0.5 \%$ \\
\hline Hotel & Large & $30432(327562)$ & & $0.4 \%$ \\
\hline Hotel/Motel & Small & 10576 (113 837) & & $1.4 \%$ \\
\hline Warehouse & & 102746 (1 105951$)$ & & $13.4 \%$ \\
\hline Apartment & High-rise & $55114(593241)$ & $55.1 \%$ & $7.2 \%$ \\
\hline Apartment & Mid-rise & $44997(484343)$ & $44.9 \%$ & $5.9 \%$ \\
\hline No Prototype & & $153270(1649785)$ & & $20.0 \%$ \\
\hline Total (2003-2007) & & 767934 (8 265 977) & & $100.0 \%$ \\
\hline
\end{tabular}

The types and floor area of buildings being constructed vary across states. Table A-2, Table A-3, and Table A-4 in the Appendix report new building construction for 2003 through 2007 by building type and state, in total square meters, total square feet, and percentage terms, respectively. Previous studies used these data to aggregate the total savings for the new construction in the CBECS categories represented by the eleven prototype buildings. Nine of the eleven prototype commercial buildings analyzed in this study are covered by data reported in Table 2-1. No data for dormitories are reported, and therefore, statewide impacts of the two types of dormitoriescannot be estimated..

Nationwide average annual construction from 2003 to 2007 is 153.6 million $\mathrm{m}^{2}\left(1.7\right.$ billion $\left.\mathrm{ft}^{2}\right)$, with significant variation across states from as low as $200000 \mathrm{~m}^{2}\left(2.2\right.$ million $\left.\mathrm{ft}^{2}\right)$ to as high as 16.5 million $\mathrm{m}^{2}$ (177.6 million $\left.\mathrm{ft}^{2}\right)$, as shown in Figure 2-1. 


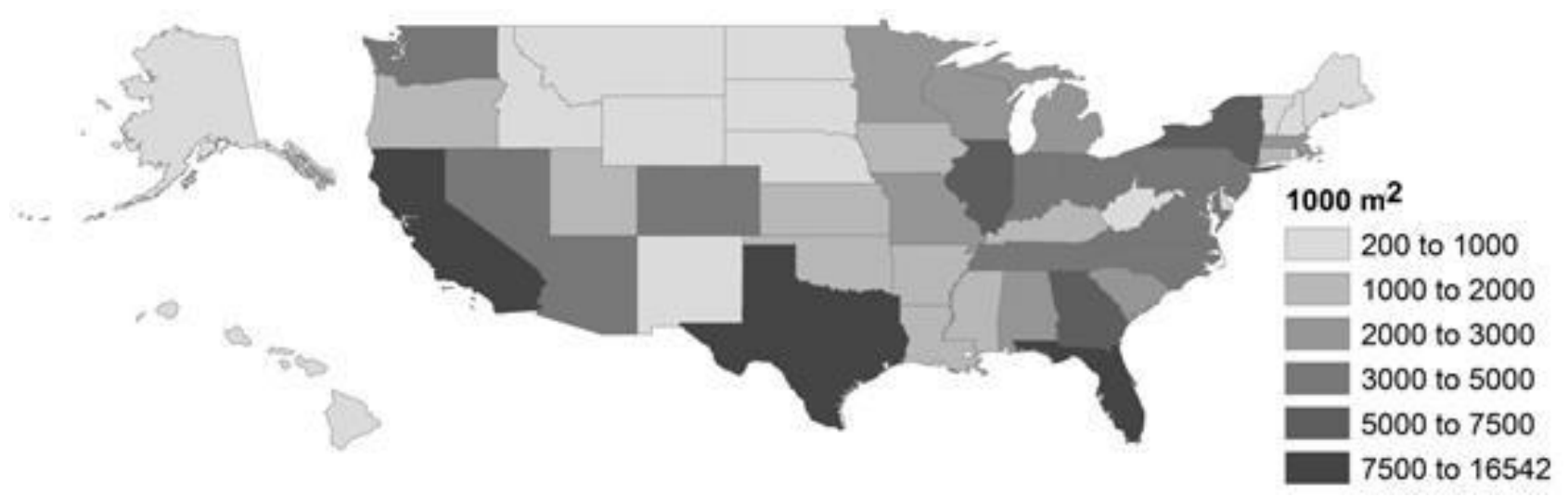

Figure 2-1 New Floor Area by State $\left(1000 \mathrm{~m}^{2}\right)$

This study considers the change in energy consumption from adoption of the Low Energy Case (LEC) design (based on ASHRAE 189.1-2009) relative to each state's energy code as of December 2011. The results are shown in Table A-5 in the Appendix in descending order of energy consumption savings. These results are also shown on the map of U.S. states in Figure $2-2$, which shows that the change in energy consumption varies from $37 \mathrm{GWh}$ to $3791 \mathrm{GWh}$. By comparing Figure 2-1 to Figure 2-2, it can be seen that the states with the greatest amount of new floor area (Florida, California, Georgia, Illinois, New York, and Texas) realize the greatest amount of energy consumption savings from adopting the LEC design.

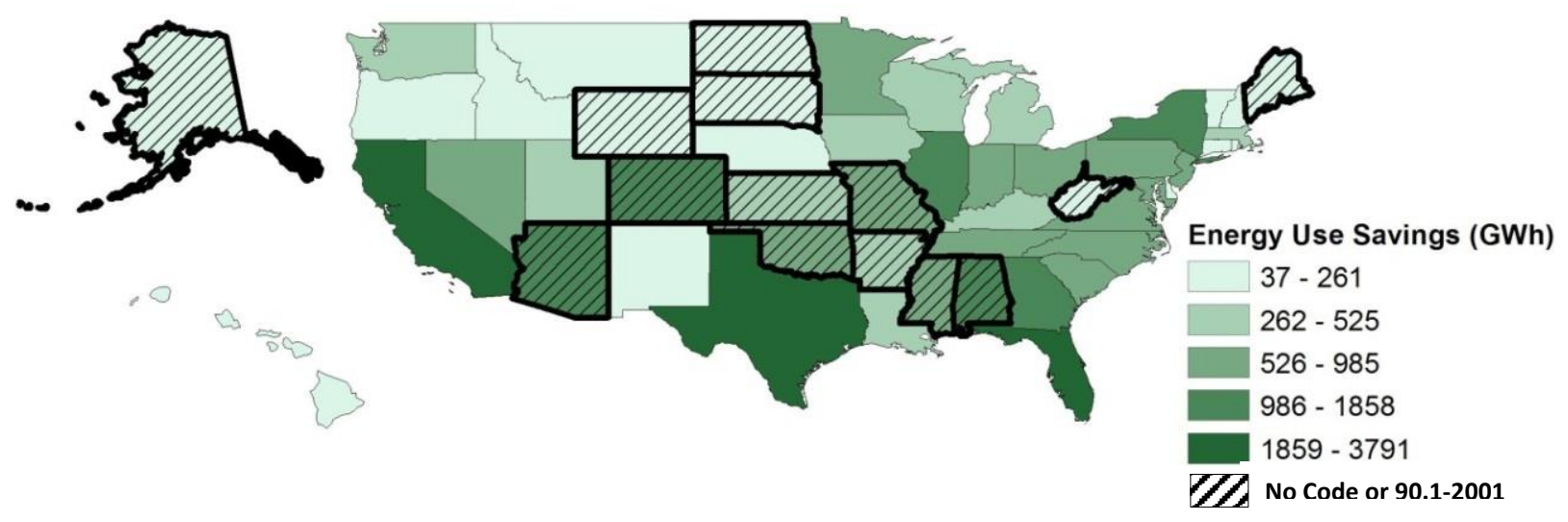

Figure 2-2 Total 10-Year Energy Use Savings by State (GWh)

This analysis approach has its limitations. Each city is weighted equally even though variation in new construction across cities could be significant, leading to overweighting cities with little to no new construction and underweighting cities with greater new construction. Additionally, the publically available construction data covers a time period (2003 to 2007) that is not representative of historical or current construction volume. The timeframe spans the five years of significant expansion immediately before the beginning of the severe economic recession. As a result, the annual construction volume for 2003 to 2007 is significantly higher than the amount of new floor area that has been constructed in more recent years. 


\section{City Cluster Weighting Approach}

In order to address the limitations of the previous approach, a more detailed new-construction database was obtained from McGraw-Hill Dodge Construction, which includes the amount of new floor area for each county in the United States for 1 for the 2012 calendar year. ${ }^{3}$ The BIRDS database results are for 228 cities across the United States, and in order to associate these city data with the county construction data it is necessary to determine which city results should be used for each county.

The approach implemented in this study to map the city-level and county-level data is referred to as "clustering," where "clusters" of counties are mapped to a particular city. In this study, a county is matched to the closest city in its state based on distance to the city from the centroid (geometric center of a two-dimensional region) of the county within the same climate zone. If there is not a city located in the same climate zone within the state, then the closet city located within the same state is selected. Of the 3140 counties, 2911 counties are matched to a city within the same climate zone while 229 are matched to a city not within the same climate zone. Figure 3-1 shows the 228 cities in the BIRDS database and their associated county clusters.

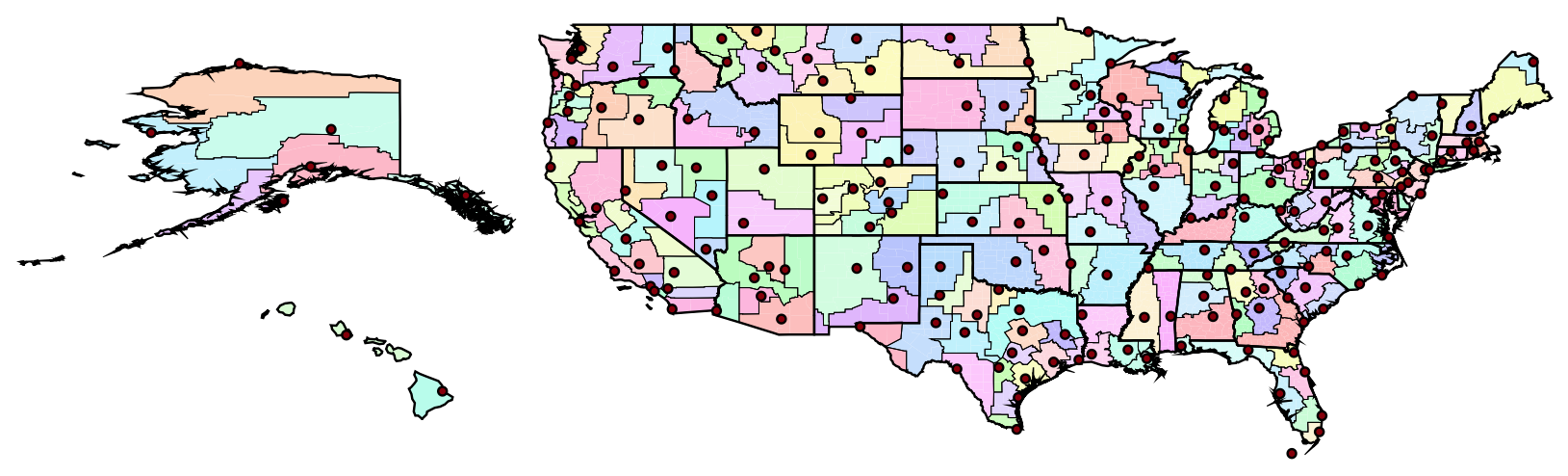

Figure 3-1 Cities and Associated (Colored) County Clusters

Three county-cluster-based weights are used to produce (1) the weighted-average percentage change in energy consumption by state, (2) the weighted-average percentage change in energy consumption by state/building type combination, (3) the aggregate change in energy consumption by state, and (4) the aggregate change in energy consumption by state/building type combination.

The average percentage change in annual energy consumption in a state is estimated using the city county cluster approach (CWA) as:

$$
\text { (11) } E_{P C T, j}^{C W A}=\sum_{i \in B}^{I_{p}} \sum_{k}^{K_{j}} W_{1, i j k}^{C W A} * E_{P C T, i j k},
$$

\footnotetext{
${ }^{3}$ McGraw-Hill Dodge Construction (2013)
} 
(12) $W_{1, i j k}^{C W A}=\frac{C F A_{i j k}}{\sum_{i}^{I} \sum_{k}^{K_{j}} C F A_{i j k}}$.

The weight $\left(W_{1, i j k}^{C W A}\right)$ is the proportion of newly constructed floor area for building type $i$ in citycounty-cluster $k$ with respect to total newly constructed floor area within state $j$ in 2012. The sum of the percentage changes for building type $i$ in city-county-cluster $k\left(E_{P C T, i j k}\right)$ multiplied by its weight over all city-county-clusters and building prototypes is the average percentage change for the state $\left(E_{P C T, j}^{C W A}\right)$.

The average percentage change in annual energy consumption in a state by building type is estimated using the city-county-cluster approach as:

(13) $E_{P C T, i k}^{C W A}=\sum_{k}^{K} W_{2, i j k}^{C W A} * E_{P C T, i j k}$,

(14) $W_{2, i j k}^{C W A}=\frac{C F A_{i j k}}{\sum_{k}^{K_{j}} C F A_{i j k}}$.

The weight $\left(W_{2, i j k}^{C W A}\right)$ is the proportion of newly constructed floor area for building type $i$ in city county-cluster $k$ with respect to total newly constructed floor area within state $j$ for building type $i$ in 2012 .

The aggregate change in annual energy consumption in a state is estimated using the citycounty-cluster approach as:

(15) $E_{C F A, j}^{C W A}=\sum_{i \in B}^{I_{p}} \sum_{k}^{K_{j}} W_{3, i j k}^{C W A} * E_{C F A, i j k}$,

(16) $W_{3, i j k}^{C W A}=\frac{C F A_{i j k} \sum_{i \in B}^{I_{p}} \sum_{k}^{K_{j}} C F A_{i j k}}{\sum_{i}^{I} \sum_{k}^{K_{j}} C F A_{i j k}}$.

The weight $\left(W_{3, i j k}^{C W A}\right)$ is the amount of newly constructed floor area by state, cluster, and building type combination normalized by the proportion of newly constructed floor area in the prototypical building types with respect to total newly constructed floor area within state $j$ in 2012.

The change per unit of floor area for building type $i$ in city-county-cluster $k\left(E_{C F A, i j k}\right)$ multiplied by its weight, and then summed over all city-county-clusters and building prototypes is the average percentage change for the state $\left(E_{C F A, j}^{C W A}\right)$.

The aggregate change in annual energy consumption in a state by building type is estimated using the city-county-cluster approach as: 
(17) $E_{C F A, i j}^{C W A}=\sum_{k}^{K_{j}} W_{4, i j k}^{C W A} * E_{C F A, i j k}$,

(18) $W_{4, j}^{C W A}=C F A_{i j k}$.

The weight is the amount of newly constructed floor area by state, cluster, and building type combination.

The crosswalk between the building types in the BIRDS database and the McGraw-Hill Dodge Construction project type is shown in Table 3-1.

Table 3-1 Crosswalk between BIRDS buildings and McGraw-Hill Dodge Construction project type and story class combinations

\section{BIRDS McGraw-Hill Dodge Construction}

\begin{tabular}{|l|l|l|}
\hline Building & Project Type & Story Class \\
\hline A04 & Apartments with 5 or more units & Mid-Rise \\
\hline A06 & Apartments with 5 or more units & High-Rise \\
\hline D04 & Lodging & Mid-Rise \\
\hline D06 & Lodging & Mid-Rise \\
\hline H15 & Lodging & High-Rise \\
\hline HS2 & Education & Low-Rise \\
\hline HS2 & Education & Mid-Rise \\
\hline HS2 & Education & High-Rise \\
\hline O03 & Office & Low-Rise \\
\hline O08 & Office & Mid-Rise \\
\hline O16 & Office & High-Rise \\
\hline RET & Stores & Low-Rise \\
\hline RET & Stores & Mid-Rise \\
\hline RET & Stores & High-Rise \\
\hline
\end{tabular}

Figure 3-2 shows the new floor area constructed in 2012 by both state and county cluster.

Depending on the state, the importance of appropriately weighting each city cluster may have a significant impact on the results. For example, major city clusters in Texas (Dallas/Fort Worth, Austin, and Houston) are realizing new construction of over $3.7 \mathrm{~m}^{2}\left(40.0\right.$ million $\left.\mathrm{ft}^{2}\right)$ while northern Texas clusters have construction of less than $372000 \mathrm{~m}^{2}\left(4.0\right.$ million $\left.\mathrm{ft}^{2}\right)$. As a result, the previous approach would lead to under/overweighting by a factor of ten, muting any differences in energy savings across cities. 

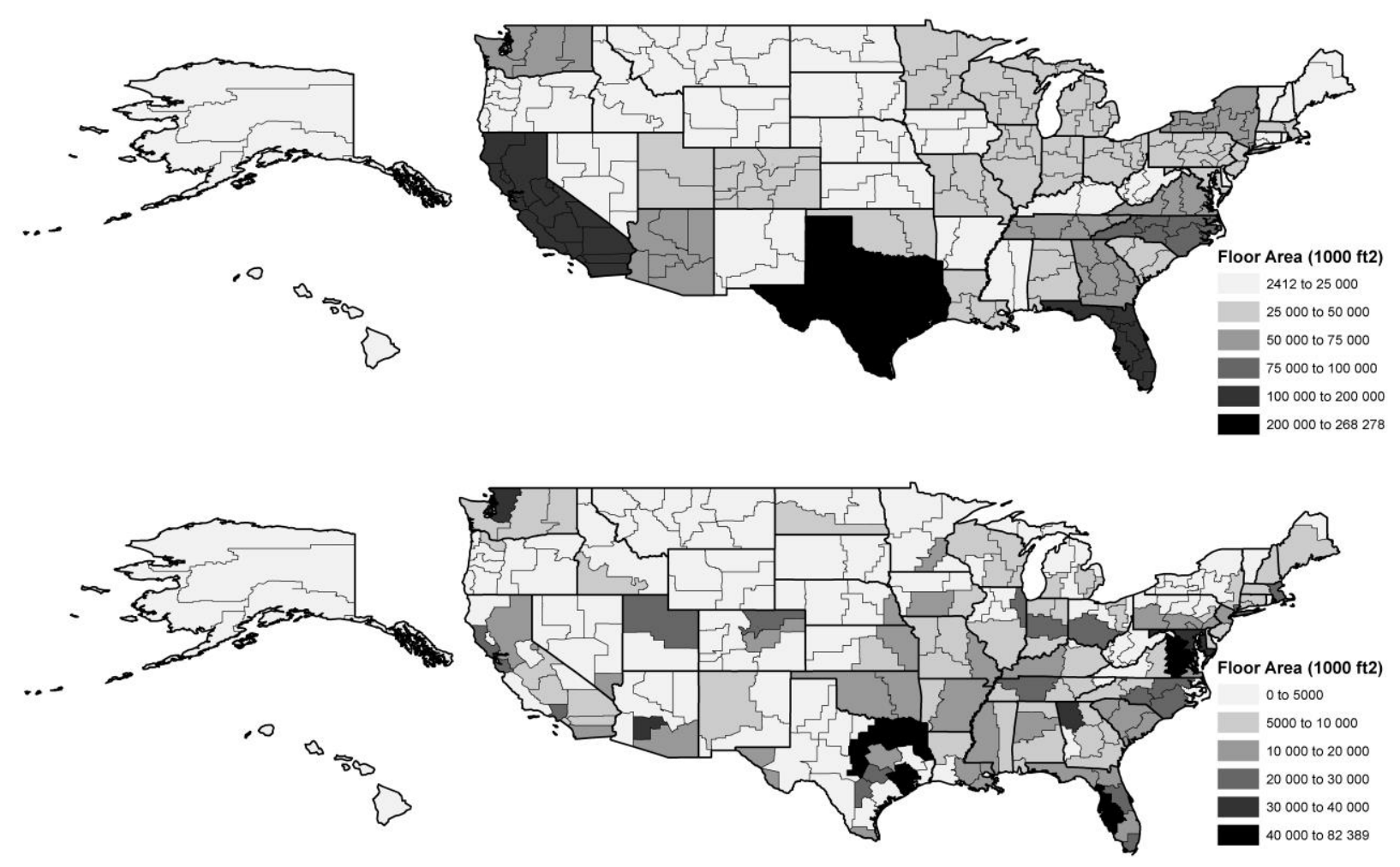

Figure 3-2 New Floor Area by State and County Cluster

This clustering approach leads to more accurate estimates than the previous approach by controlling for both the variation in building performance across a state due to weather as well as the amount of new construction for each building type for each location considered in this study. Additionally, the more recent new construction data (2012) is more representative of current and near-future construction volume because the data is post-recession and less than two years old. 


\section{Energy Consumption Savings Comparison}

In this chapter, the impact of a nationwide adoption of the LEC design as a state's energy code is estimated using the two approaches defined in Section 2 and Section 3 for new construction in 2012. Results are first analyzed in detail for a single state (New York) to show how differences in the amount of new construction across city clusters will impact the magnitude of the energy consumption savings realized by adopting the LEC design as a state's energy code. These results are then calculated and compared for all states in the nation. Finally, the aggregate results are analyzed at the Census region and national level.

\subsection{Detailed Impacts for New York State}

The amount of new floor area constructed in New York in 2012 was 5.0 million $\mathrm{m}^{2}$ (53.4 million $\mathrm{ft}^{2}$ ). The city average approach calculates the average change in energy consumption per unit of floor area for all cities for each building type, and associates statewide newly constructed floor area to each building type. The city cluster approach uses the same amount of new construction, but each city cluster is weighted based on its associated amount of construction for each building type. Figure 4-1 shows that New York City is the only city cluster that had more than 1.9 million $\mathrm{m}^{2}\left(20.0\right.$ million $\left.\mathrm{ft}^{2}\right)$ of new construction, Albany is the only cluster with $465000 \mathrm{~m}^{2}$ to $929000 \mathrm{~m}^{2}$ (5.0 million $\mathrm{ft}^{2}$ to 10.0 million $\left.\mathrm{ft}^{2}\right)$, and the other five cities have less than $465000 \mathrm{~m}^{2}\left(5.0\right.$ million $\left.\mathrm{ft}^{2}\right)$. As a result, New York is an ideal state with which to test the impact of using the more precise city weighting approach.

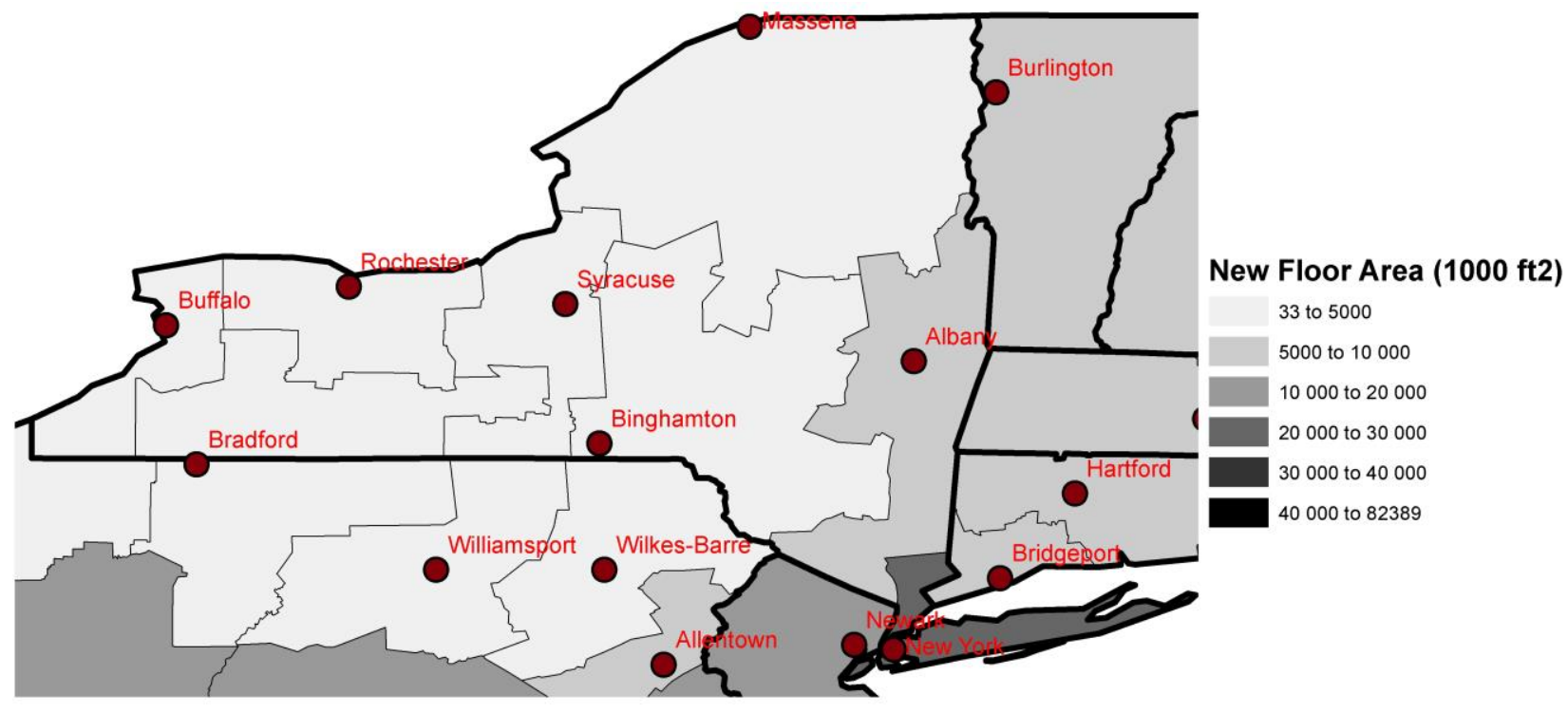

Figure 4-1 New Floor Area by City Cluster for New York

Table 4-1 shows the percentage change in energy consumption and aggregate change in energy consumption for New York State for each weighting approach. The city cluster weighting approach leads to a 1.7 percentage point decrease $(11.8 \%$ versus $13.5 \%)$ in the average annual percentage reduction in energy consumption relative to the city average approach. The impact 
varies across building types due to different types of buildings being constructed in different locations of the state. The greatest difference occurs for the 16-story office building (6.6\%) and 15 -story hotel $(4.9 \%)$.

Table 4-1 Change in Energy Consumption by Weighting Approach and Building Type New York

\begin{tabular}{|c|c|c|c|c|}
\hline \multirow{2}{*}{$\begin{array}{c}\text { Building } \\
\text { Type }\end{array}$} & \multicolumn{2}{|c|}{ Change in Energy Use (\%) } & \multicolumn{2}{|c|}{ Change in Energy Use (GWh) } \\
\hline & City Average & City Cluster & City Average & City Cluster \\
\hline A04 & -9.2 & -10.3 & -28428 & -28335 \\
\hline A06 & -9.6 & -11.1 & -28569 & -26529 \\
\hline D05 ${ }^{1}$ & -10.1 & -10.4 & -10873 & -10645 \\
\hline H15 & -11.2 & -16.1 & -12364 & -15669 \\
\hline HS2 & -6.2 & -8.7 & -9227 & -10312 \\
\hline $\mathrm{O} 03$ & -16.9 & -16.8 & -5083 & -5127 \\
\hline O08 & -17.0 & -16.5 & -2091 & -2301 \\
\hline O16 & -13.9 & -20.5 & -9746 & -13103 \\
\hline RET & -12.4 & -11.1 & -16832 & -15699 \\
\hline Total & -11.8 & -13.5 & -123213 & -127720 \\
\hline
\end{tabular}

The aggregate change in energy consumption is shown to vary across the two weighting approaches. Based on the City Average Approach approach, the estimated yearly energy consumption savings for the prototypical buildings in New York over a 10-year study period is $123213 \mathrm{GWh}$. Based on the city cluster approach, the estimated energy consumption savings is $128000 \mathrm{GWh}$.

\subsection{Aggregate Impacts}

The total change in energy consumption by state based on the amount of construction in 2012, for each of the weighting approaches, is presented in Table 4-2. Averaged over all states, the city average weighting approach results in smaller savings, per state, than does the cluster weighting approach (average of $360 \mathrm{GWh}$ ). However, the effects are not consistent. For 19 states, the savings are smaller using the city average approach, with Arizona experiencing the largest total difference. For 26 states, the savings are larger using the cluster approach, with Florida showing the largest total difference. For five states, the city average and clustering approach produce identical results because there is only one city for each of those states, in which case there are not multiple cities for which to weight. The difference in nationwide aggregate savings is $17985 \mathrm{GWh}$, or $0.3 \%$ of total nationwide aggregate savings. 
Table 4-2 Change in State Energy Consumption (GWh) by Weighting Approach

\begin{tabular}{|c|c|c|c|c|c|c|c|}
\hline STATE & $\begin{array}{l}\text { CITY } \\
\text { AVG }\end{array}$ & CLUSTER & $\begin{array}{l}\text { PCT } \\
\text { DIFF }\end{array}$ & STATE & $\begin{array}{l}\text { CITY } \\
\text { AVG }\end{array}$ & CLUSTER & $\begin{array}{l}\text { PCT } \\
\text { DIFF }\end{array}$ \\
\hline ALABAMA & -172679 & -172154 & $-0.3 \%$ & MONTANA & -12522 & -14246 & $13.8 \%$ \\
\hline ALASKA & -20224 & -24752 & $22.4 \%$ & NEBRASKA & -28594 & -30415 & $6.4 \%$ \\
\hline ARIZONA & -227327 & -213284 & $-6.2 \%$ & NEVADA & -27572 & -28041 & $1.7 \%$ \\
\hline ARKANSAS & -100822 & -100857 & $0.0 \%$ & NEW HAMPSHIRE & -16738 & -16738 & $0.0 \%$ \\
\hline CALIFORNIA & -321313 & -325799 & $1.4 \%$ & NEW JERSEY & -76482 & -77550 & $1.4 \%$ \\
\hline COLORADO & -218658 & -227666 & $4.1 \%$ & NEW MEXICO & -17417 & -17191 & $-1.3 \%$ \\
\hline CONNECTICUT & -30820 & -30926 & $0.3 \%$ & NEW YORK & -203376 & -210815 & $3.7 \%$ \\
\hline DELAWARE & -16686 & -16686 & $0.0 \%$ & NORTH CAROLINA & -161947 & -161884 & $0.0 \%$ \\
\hline FLORIDA & -300706 & -314072 & $4.4 \%$ & NORTH DAKOTA & -86962 & -86732 & $-0.3 \%$ \\
\hline GEORGIA & -172637 & -169557 & $-1.8 \%$ & OHIO & -120417 & -121847 & $1.2 \%$ \\
\hline HAWAII & -18839 & -19842 & $5.3 \%$ & OKLAHOMA & -154549 & -153724 & $-0.5 \%$ \\
\hline IDAHO & -21766 & -21135 & $-2.9 \%$ & OREGON & -27474 & -29457 & $7.2 \%$ \\
\hline ILLINOIS & -133006 & -126683 & $-4.8 \%$ & PENNSYLVANIA & -136972 & -141259 & $3.1 \%$ \\
\hline INDIANA & -119282 & -119375 & $0.1 \%$ & RHODE ISLAND & -4991 & -4991 & $0.0 \%$ \\
\hline IOWA & -60532 & -58014 & $-4.2 \%$ & SOUTH CAROLINA & -100796 & -102879 & $2.1 \%$ \\
\hline KANSAS & -116306 & -120004 & $3.2 \%$ & SOUTH DAKOTA & -37712 & -37759 & $0.1 \%$ \\
\hline KENTUCKY & -49077 & -49512 & $0.9 \%$ & TENNESSEE & -160339 & -162684 & $1.5 \%$ \\
\hline LOUISIANA & -69830 & -70731 & $1.3 \%$ & TEXAS & -644137 & -644976 & $0.1 \%$ \\
\hline MAINE & -35146 & -31486 & $-10.4 \%$ & UTAH & -72754 & -76154 & $4.7 \%$ \\
\hline MARYLAND & -102881 & -102881 & $0.0 \%$ & VERMONT & -10934 & -10934 & $0.0 \%$ \\
\hline MASSACHUSETTS & -93607 & -95153 & $1.7 \%$ & VIRGINIA & -153217 & -152597 & $-0.4 \%$ \\
\hline MICHIGAN & -58388 & -54930 & $-5.9 \%$ & WASHINGTON & -82713 & -82012 & $-0.8 \%$ \\
\hline MINNESOTA & -150063 & -141749 & $-5.5 \%$ & WEST VIRGINIA & -39578 & -37785 & $-4.5 \%$ \\
\hline MISSISSIPPI & -135049 & -135985 & $0.7 \%$ & WISCONSIN & -88896 & -87158 & $-2.0 \%$ \\
\hline MISSOURI & -171388 & -169205 & $-1.3 \%$ & WYOMING & -26371 & -26211 & $-0.6 \%$ \\
\hline
\end{tabular}

Figure 4-2 shows that the state-level results for the city cluster approach are relatively similar to the results using the city average approach. The energy consumption changes by $2.5 \%$ or less for 31 states $(62 \%)$ and $5.0 \%$ or less for 41 states $(82 \%)$. Using the city cluster approach leads to energy consumption changes greater than $10 \%$ for only three states (Alaska, Montana, and Maine). All three states have relatively small amounts of new construction, which can cause small changes in magnitude to be large percentages. 


\section{Percentage Difference between Cluster Approaches and City Average}

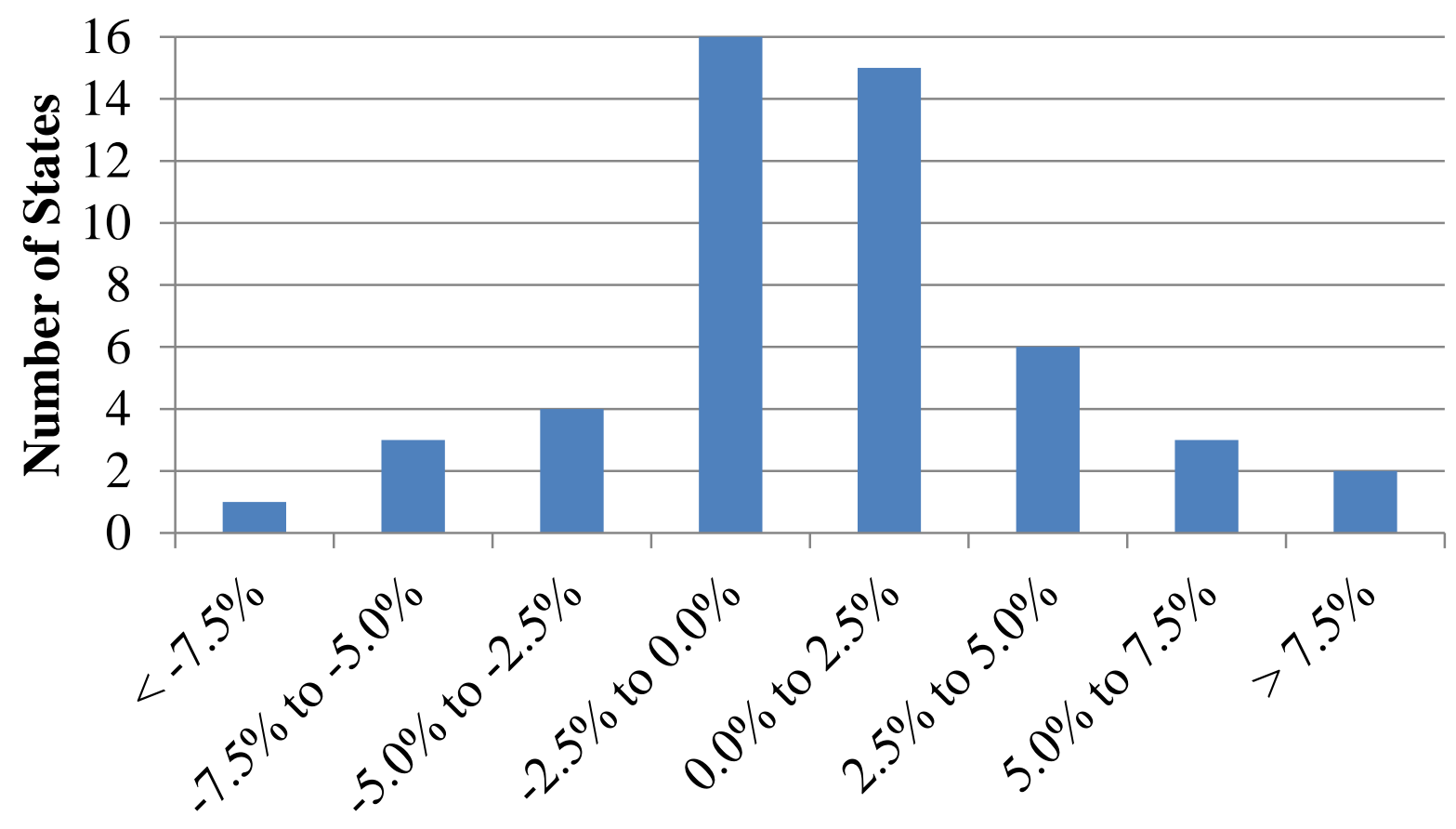

Figure 4-2 Difference between Energy Savings using the City Cluster Approach relative to City Average Approach 


\section{Discussion, Limitations, and Future Research}

This study explores the importance of increased precision in the construction data used to estimate the state-level impacts of more stringent energy efficiency requirements in newly constructed commercial buildings based on the BIRDS database. Newly constructed floor area data for 2012 was obtained for each county in the United States to assist in increasing the accuracy of these impact estimates relative to state-level construction data. Each county is associated with one of the 228 cities in the BIRDS database, creating a "cluster" of counties that use the average performance for each building type for the associated city to estimate the impacts of adopting a more stringent state energy code.

\subsection{Analysis}

A number of key results have been identified from the analysis in this study. For many states, the amount of new construction by city cluster varies significantly. For example, new construction is over three times greater in the New York City cluster than most of the other city clusters in the State of New York. As a result, there is potential that more detailed construction data could lead to significant impacts on the estimated energy savings. The state average percentage reduction in energy use from adopting the Low Energy Case (LEC) as New York's state energy code for a given building type can be significantly different depending on the weighting approach used in the analysis, ranging from 0.3 percentage points to 6.6 percentage points, with an average of 1.7 percentage points $(11.8 \%$ using the city average approach versus $13.5 \%$ using the city cluster weighting approach). Similarly, using the city cluster weighting approach, the aggregate energy savings for a given building type varies by $0.3 \%$ to $34.4 \%$ relative to the simple average approach with the total aggregate savings for all building types in the state varying by $3.7 \%$. At the building level, aggregate results can vary significantly while at the state level, it appears that the results are relatively similar. More precise construction data can increase the accuracy of the results, but the relative magnitude of the results is similar.

The city cluster weighting approach leads to 19 states realizing smaller savings and 26 states realizing larger savings relative to the city average approach. Five states realize identical results because there is only one city for each of those states in the BIRDS database, in which case there are not multiple cities for which to weight. Since states are split between realizing smaller and larger estimated savings, the difference in nationwide aggregate savings is small at $0.3 \%$ of the total nationwide aggregate savings.

The state-level results for the city cluster approach are relatively similar to the results using the city average approach. The energy consumption changes by $2.5 \%$ or less for 31 states (62\%) and $5.0 \%$ or less for 41 states ( $82 \%$ ). Using the city cluster approach leads to greater than $10 \%$ for only three states (Alaska, Montana, and Maine). All three states have relatively small amounts of new construction, which can cause small changes in magnitude to be large changes in percentage terms. 


\subsection{Limitations and Future Research}

This study attempts to improve upon the analysis approach from previous research using the BIRDS database. Based on the results, it appears that the accuracy of the energy savings estimates are impacted by the weighting approach used in the analysis. The city cluster approach described in this study alleviates some of the inherent issues/problems created in using the equal weighting approach. However, there are still aspects of this approach that can be improved upon to increase the accuracy of the results.

First, the current cluster approach restricted clustering across state borders even though the closest city may be in a bordering state. An example of this can be seen in Figure 5-1, where the counties within Kentucky and the surrounding states are mapped to a city that is often much further away than a city in another state. As a result, the climatic and economic conditions for those counties may not be matched to the optimal (i.e., most representative) city in the database.

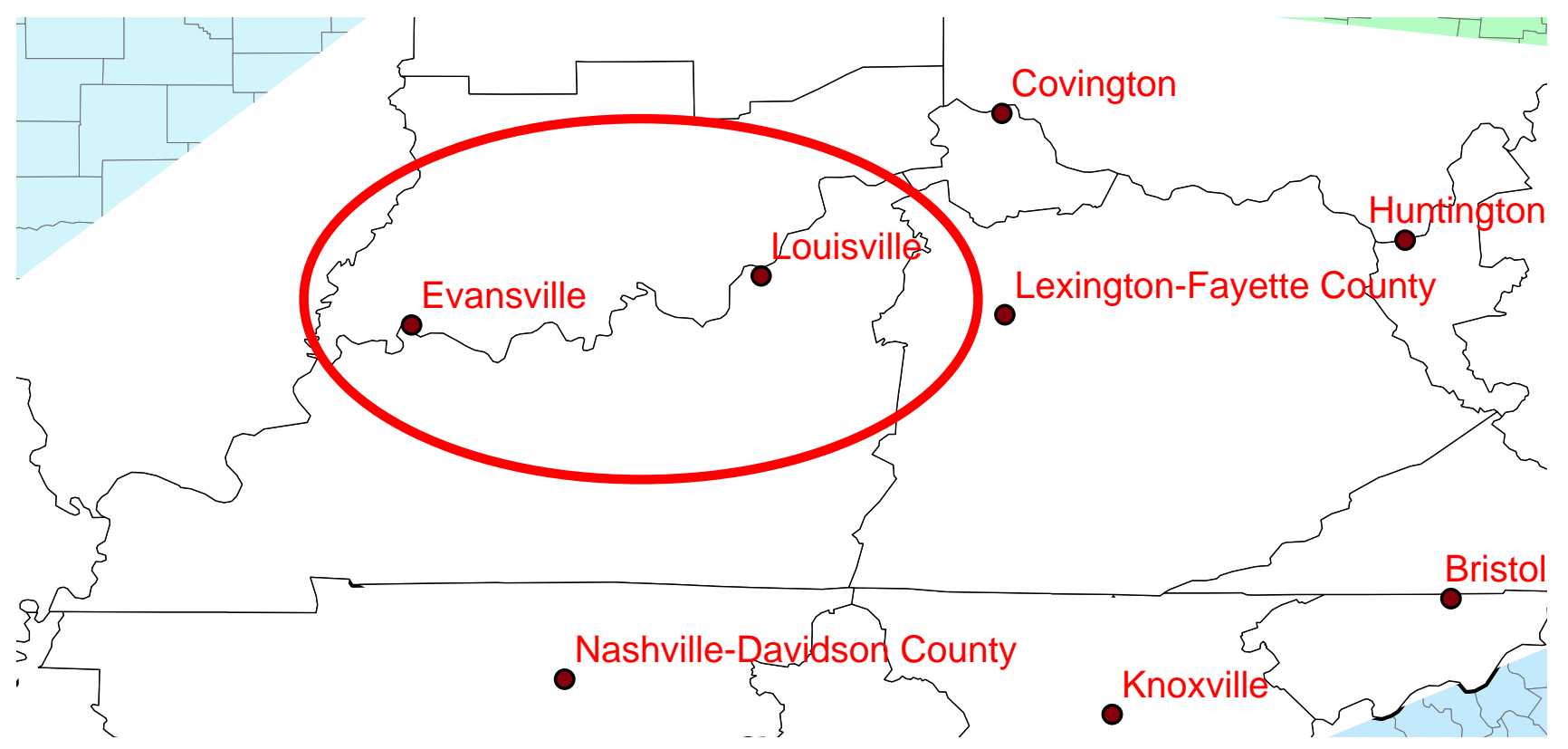

Figure 5-1 City Clusters - Kentucky and Surrounding States

The reason for the state border restriction was because the results from the BIRDS database used for this study are based on comparison of the LEC design to each state's energy code as of December 2011, which may vary across states. Future work should use the results in the BIRDS database to match each county with the closest city regardless of state, but use the results for the standard edition that meets the county's state energy code. For example, the counties on the northern border of western Kentucky will be matched to the energy performance of buildings located in Evansville, Indiana instead of Louisville, Kentucky while using the building designs that meet Kentucky's state energy code. 
Second, the results are estimated using the current eleven building types in the BIRDS database and the new construction data associated with those building types. The results are then extrapolated to the entire new building stock. Future research should incorporate additional building types into the BIRDS database to increase the fraction of building stock directly accounted for in BIRDS, which will increase the accuracy of the estimated impacts.

Third, the analysis in this study updates the impact estimates for energy consumption savings. The same city cluster weighting approach should be applied to the other sustainability metrics included in the BIRDS database: energy costs, life-cycle costs, and the twelve environmental impact categories.

Finally, future research should test the sensitivity of the sustainability performance results to other underlying assumptions in the analysis approach for which city and/or county level data may be available. For example, electricity prices can vary significantly across cities in a state. Doing so should further increase the accuracy of the results. 


\section{References}

ArcMap 10.2 software, ArcGIS desktop package, ESRI, Redlands, CA, http://www.esri.com/.

J. Kneifel, 2011, Prototype Commercial Buildings for Energy and Sustainability Assessment: Whole Building Energy Simulation Design, September 2011, NIST, Technical Note 1716.

J. Kneifel, 2012, Prototype Commercial Buildings for Energy and Sustainability Assessment: Design Specification, Life-Cycle Costing and Carbon Assessment, January 2012, NIST, Technical Note 1732.

J. Kneifel, 2013a, Benefits and Costs of Energy Standard Adoption in New Commercial Buildings, February 2013, NIST, Special Publication 1147.

J. Kneifel, 2013b, Benefits and Costs of Energy Standard Adoption in New Commercial Buildings: Northeast Census Region, February 2013, NIST, Special Publication 1148-1.

J. Kneifel, 2013c, Benefits and Costs of Energy Standard Adoption in New Commercial Buildings: Midwest Census Region, February 2013, NIST, Special Publication 1148-2.

J. Kneifel, 2013d, Benefits and Costs of Energy Standard Adoption in New Commercial Buildings: South Census Region, February 2013, NIST, Special Publication 1148-3.

J. Kneifel, 2013e, Benefits and Costs of Energy Standard Adoption in New Commercial Buildings: West Census Region, March 2013, NIST, Special Publication 1148-4.

McGraw-Hill Dodge Construction, 2013, County-level new construction floor area database-2012.

U.S. Energy Information Administration, 2003 Commercial Buildings Energy Consumption Survey (CBECS), http://www.eia.gov/consumption/commercial/. 


\section{A Building Type, New Construction, and Energy Savings}

\section{Table A-1 CBECS Categories and Subcategories}

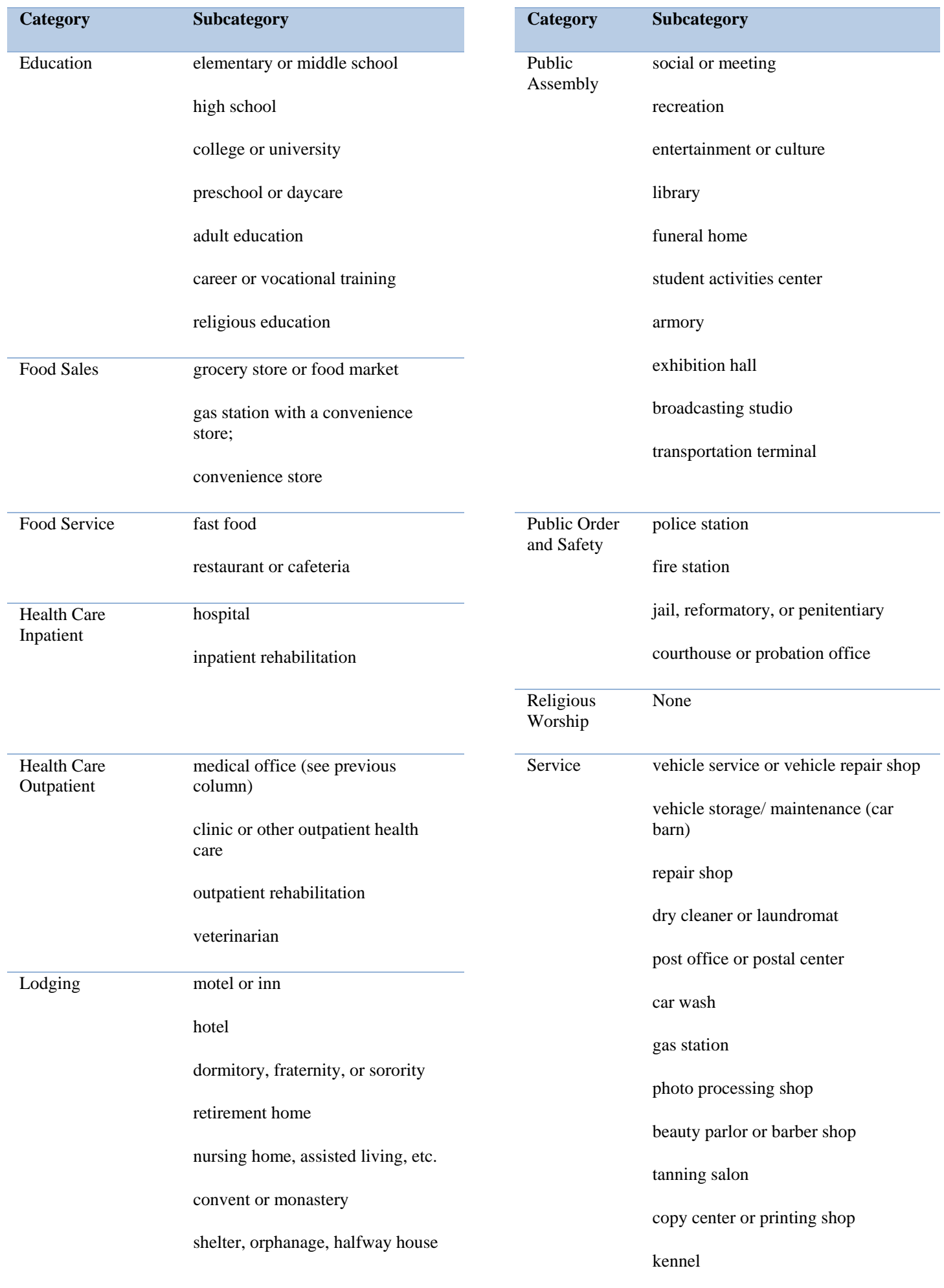




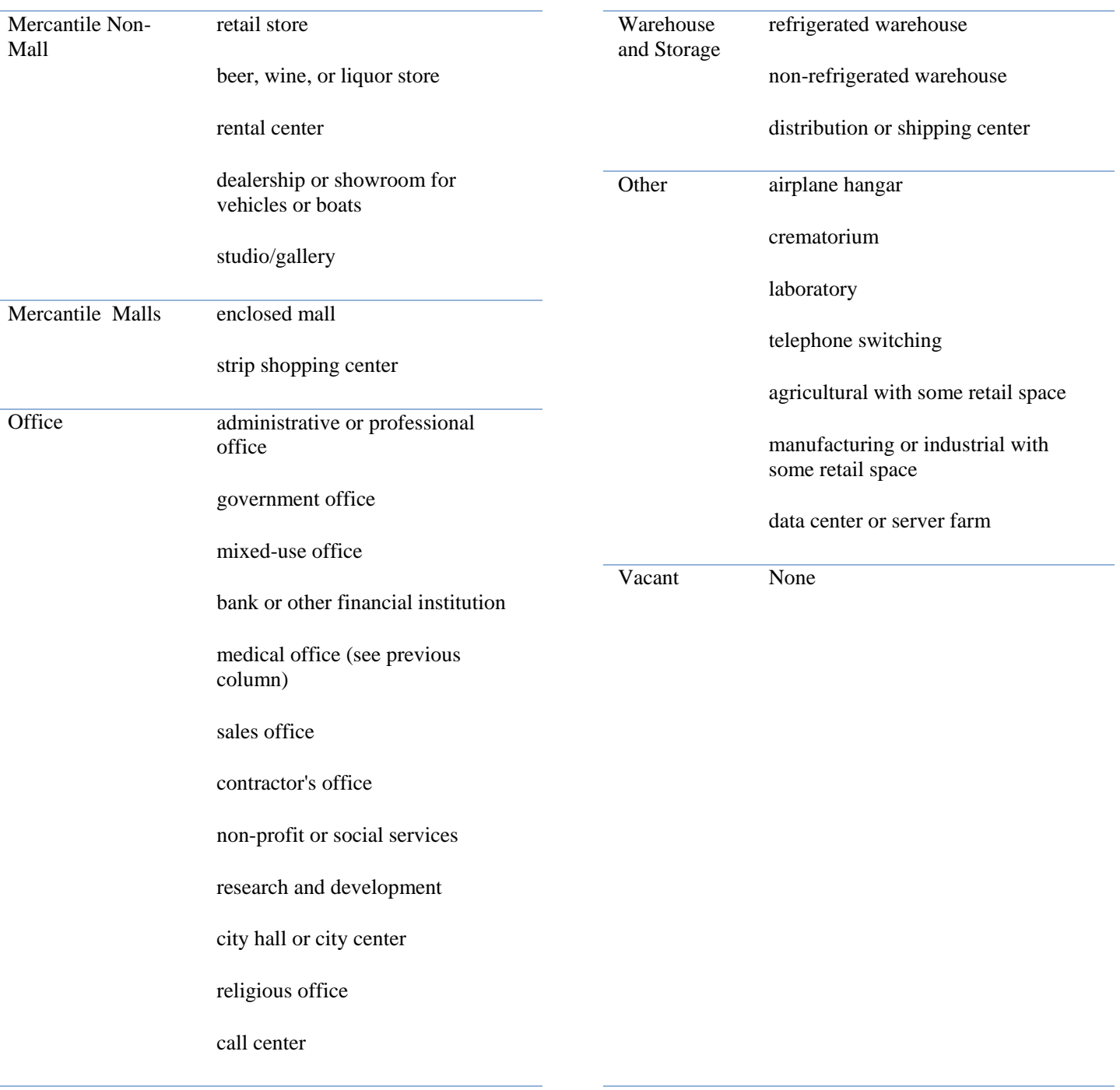


Table A-2 New Commercial Building Construction Volume for 2003 through 2007 by State and Building Type (S-I)

\begin{tabular}{|c|c|c|c|c|c|c|c|c|c|c|c|}
\hline \multirow{2}{*}{$\begin{array}{l}\text { State } \\
\text { AK }\end{array}$} & \multicolumn{11}{|c|}{ Building Construction Volume $\left(1,000 \mathrm{~m}^{2}\right)$} \\
\hline & $\begin{array}{r}\text { Apartment } \\
19\end{array}$ & $\begin{array}{r}\text { Healthcare } \\
130\end{array}$ & $\begin{array}{l}\text { Hotel } \\
\quad 126\end{array}$ & $\begin{array}{l}\text { Office } \\
226\end{array}$ & $\begin{array}{r}\text { Public Assembly } \\
111\end{array}$ & $\begin{array}{r}\text { Restaurant } \\
13\end{array}$ & ${ }_{208}^{\text {Retail }}$ & $\begin{array}{r}\text { School } \\
231\end{array}$ & $\begin{array}{r}\text { Warehouse } \\
126\end{array}$ & $\begin{array}{r}\text { No Prototype } \\
259\end{array}$ & $\begin{array}{r}\text { Total } \\
1448\end{array}$ \\
\hline $\mathrm{AL}$ & 801 & 705 & 853 & 1504 & 639 & 169 & 2485 & 1534 & 842 & 1740 & 11272 \\
\hline AR & 118 & 465 & 483 & 647 & 335 & 77 & 1359 & 1295 & 335 & 815 & 5928 \\
\hline $\mathrm{AZ}$ & 1043 & 1505 & 1047 & 4030 & 1180 & 271 & 4891 & 2294 & 3721 & 3808 & 23790 \\
\hline $\mathrm{CA}$ & 9761 & 3310 & 3129 & 9219 & 3092 & 534 & 10623 & 7085 & 13364 & 12345 & 72462 \\
\hline $\mathrm{CO}$ & 2033 & 1387 & 997 & 2158 & 708 & 199 & 2896 & 1654 & 1541 & 2889 & 16461 \\
\hline CT & 611 & 403 & 489 & 618 & 510 & 65 & 1245 & 1194 & 817 & 1271 & 7223 \\
\hline DC & 1174 & 71 & 111 & 1462 & 112 & 4 & 104 & 191 & 34 & 830 & 4092 \\
\hline DE & 70 & 155 & 124 & 224 & 119 & 16 & 237 & 290 & 160 & 323 & 1719 \\
\hline FL & 21397 & 3399 & 2979 & 9031 & 3124 & 678 & 11904 & 7760 & 9692 & 12748 & 82712 \\
\hline GA & 3696 & 1551 & 1510 & 3630 & 1212 & 331 & 5893 & 5580 & 7449 & 5350 & 36202 \\
\hline $\mathrm{HI}$ & 1280 & 91 & 92 & 171 & 59 & 9 & 273 & 92 & 132 & 485 & 2682 \\
\hline IA & 143 & 639 & 427 & 999 & 657 & 74 & 1350 & 1262 & 621 & 1062 & 7234 \\
\hline ID & 233 & 372 & 221 & 716 & 230 & 46 & 699 & 636 & 360 & 496 & 4008 \\
\hline IL & 7303 & 1765 & 1304 & 2930 & 1714 & 232 & 5660 & 3083 & 6473 & 4179 & 34643 \\
\hline IN & 360 & 1728 & 856 & 1746 & 1323 & 255 & 3302 & 2558 & 3771 & 2415 & 18313 \\
\hline KS & 98 & 533 & 353 & 877 & 295 & 97 & 1122 & 826 & 513 & 670 & 5384 \\
\hline KY & 268 & 757 & 643 & 1167 & 760 & 138 & 1667 & 1270 & 2001 & 1106 & 9778 \\
\hline LA & 169 & 650 & 807 & 1175 & 593 & 135 & 1736 & 842 & 1011 & 1379 & 8498 \\
\hline MA & 2959 & 728 & 884 & 1103 & 632 & 121 & 1772 & 1356 & 854 & 2484 & 12895 \\
\hline MD & 3341 & 813 & 826 & 2802 & 580 & 109 & 1549 & 1527 & 1989 & 3388 & 16924 \\
\hline $\mathrm{ME}$ & 64 & 209 & 166 & 224 & 134 & 34 & 566 & 313 & 281 & 494 & 2485 \\
\hline MI & 446 & 1797 & 713 & 1696 & 1359 & 200 & 3245 & 2058 & 864 & 2442 & 14820 \\
\hline MN & 1437 & 1018 & 473 & 1633 & 527 & 102 & 2135 & 1175 & 803 & 2342 & 11645 \\
\hline MO & 875 & 940 & 881 & 1226 & 780 & 158 & 2513 & 1626 & 819 & 1972 & 11791 \\
\hline MS & 150 & 336 & 479 & 631 & 411 & 55 & 1166 & 743 & 1593 & 692 & 6255 \\
\hline MT & 45 & 122 & 118 & 149 & 94 & 18 & 253 & 174 & 76 & 142 & 1190 \\
\hline $\mathrm{NC}$ & 1607 & 1362 & 1178 & 3368 & 1119 & 230 & 4472 & 3418 & 1910 & 3520 & 22185 \\
\hline ND & 7 & 118 & 91 & 138 & 113 & 14 & 331 & 174 & 57 & 100 & 1145 \\
\hline $\mathrm{NE}$ & 147 & 453 & 303 & 631 & 331 & 54 & 1149 & 514 & 340 & 676 & 4599 \\
\hline $\mathrm{NH}$ & 141 & 227 & 226 & 276 & 154 & 51 & 648 & 411 & 191 & 438 & 2763 \\
\hline NJ & 2807 & 796 & 943 & 1235 & 774 & 112 & 2494 & 2627 & 3008 & 2587 & 17382 \\
\hline NM & 89 & 247 & 418 & 617 & 350 & 62 & 765 & 752 & 292 & 491 & 4083 \\
\hline NV & 2867 & 528 & 2963 & 1626 & 1195 & 157 & 2382 & 960 & 1669 & 3231 & 17579 \\
\hline NY & 11622 & 1639 & 1959 & 3330 & 1075 & 210 & 3633 & 2247 & 1286 & 3354 & 30354 \\
\hline $\mathrm{OH}$ & 635 & 2452 & 925 & 2674 & 1266 & 372 & 5132 & 4452 & 3382 & 3243 & 24533 \\
\hline OK & 115 & 794 & 512 & 763 & 878 & 141 & 1364 & 1179 & 932 & 1271 & 7950 \\
\hline OR & 1253 & 918 & 360 & 922 & 383 & 68 & 1382 & 651 & 1142 & 1648 & 8727 \\
\hline PA & 1503 & 1908 & 1406 & 2424 & 1354 & 219 & 3762 & 3660 & 3512 & 3556 & 23305 \\
\hline RI & 238 & 60 & 192 & 251 & 81 & 26 & 278 & 197 & 114 & 236 & 1674 \\
\hline SC & 1981 & 746 & 563 & 1539 & 539 & 168 & 2600 & 2222 & 1101 & 2132 & 13590 \\
\hline SD & 13 & 119 & 86 & 257 & 126 & 13 & 341 & 268 & 88 & 205 & 1515 \\
\hline $\mathrm{TN}$ & 987 & 1036 & 683 & 2296 & 733 & 199 & 3581 & 1809 & 2698 & 2337 & 16360 \\
\hline TX & 5548 & 4508 & 3571 & 8328 & 3325 & 849 & 13121 & 12693 & 10609 & 9676 & 72230 \\
\hline UT & 622 & 569 & 314 & 1365 & 475 & 76 & 1424 & 1269 & 1274 & 1201 & 8590 \\
\hline VA & 3502 & 1011 & 1361 & 3693 & 1096 & 200 & 3014 & 2387 & 1826 & 4406 & 22495 \\
\hline VT & 161 & 99 & 96 & 113 & 71 & 6 & 63 & 136 & 88 & 165 & 998 \\
\hline WA & 3397 & 1085 & 871 & 2435 & 833 & 107 & 2504 & 1841 & 1880 & 3598 & 18551 \\
\hline WI & 906 & 1519 & 583 & 1556 & 746 & 137 & 2489 & 1129 & 882 & 1981 & 11928 \\
\hline WV & 65 & 215 & 148 & 193 & 117 & 39 & 668 & 484 & 179 & 288 & 2397 \\
\hline WY & 4 & 72 & 166 & 66 & 127 & 9 & 158 & 254 & 67 & 228 & 1151 \\
\hline Total & 100111 & 48059 & 41007 & 92089 & 38550 & 7661 & 128609 & 94383 & 98773 & 118693 & 767935 \\
\hline
\end{tabular}


Table A-3 New Commercial Building Construction Volume for 2003 through 2007 by State and Building Type (I-P)

\begin{tabular}{|c|c|c|c|c|c|c|c|c|c|c|c|}
\hline \multirow{2}{*}{ State } & \multicolumn{11}{|c|}{ Building Construction Volume $\left(1,000 \mathrm{ft}^{2}\right)$} \\
\hline & Apartment & Healthcare & Hotel & Office & Public Assembly & Restaurant & Retail & School & Warehouse & No Prototype & Total \\
\hline AK & 201 & 1401 & 1357 & 2428 & 1190 & 137 & 2240 & 2484 & 1356 & 2787 & 15581 \\
\hline $\mathrm{AL}$ & 8619 & 7587 & 9184 & 16191 & 6876 & 1821 & 26748 & 16514 & 9060 & 18729 & 121329 \\
\hline AR & 1272 & 5000 & 5198 & 6962 & 3611 & 829 & 14624 & 13936 & 3609 & 8768 & 63810 \\
\hline $\mathrm{AZ}$ & 11223 & 16195 & 11272 & 43383 & 12701 & 2918 & 52646 & 24692 & 40052 & 40986 & 256068 \\
\hline $\mathrm{CA}$ & 105071 & 35633 & 33678 & 99228 & 33281 & 5747 & 114344 & 76262 & 143853 & 132882 & 779978 \\
\hline $\mathrm{CO}$ & 21885 & 14926 & 10735 & 23225 & 7618 & 2142 & 31177 & 17804 & 16582 & 31094 & 177186 \\
\hline CT & 6582 & 4333 & 5261 & 6651 & 5485 & 698 & 13403 & 12856 & 8798 & 13679 & 77746 \\
\hline DC & 12636 & 769 & 1199 & 15734 & 1202 & 38 & 1122 & 2051 & 363 & 8934 & 44047 \\
\hline $\mathrm{DE}$ & 755 & 1672 & 1330 & 2410 & 1282 & 173 & 2551 & 3126 & 1722 & 3480 & 18501 \\
\hline FL & 230315 & 36591 & 32071 & 97212 & 33622 & 7299 & 128133 & 83524 & 104327 & 137213 & 890306 \\
\hline GA & 39780 & 16699 & 16254 & 39076 & 13043 & 3563 & 63430 & 60062 & 80180 & 57586 & 389672 \\
\hline HI & 13773 & 979 & 989 & 1838 & 630 & 95 & 2939 & 985 & 1417 & 5220 & 28865 \\
\hline IA & 1542 & 6875 & 4598 & 10749 & 7069 & 796 & 14534 & 13586 & 6688 & 11426 & 77863 \\
\hline ID & 2506 & 4001 & 2375 & 7703 & 2478 & 493 & 7526 & 6847 & 3876 & 5343 & 43147 \\
\hline IL & 78609 & 18998 & 14037 & 31542 & 18451 & 2497 & 60928 & 33180 & 69674 & 44977 & 372893 \\
\hline IN & 3875 & 18600 & 9210 & 18791 & 14242 & 2747 & 35539 & 27535 & 40591 & 25992 & 197123 \\
\hline KS & 1057 & 5734 & 3795 & 9442 & 3178 & 1039 & 12076 & 8892 & 5521 & 7216 & 57950 \\
\hline KY & 2888 & 8150 & 6922 & 12558 & 8185 & 1489 & 17941 & 13672 & 21538 & 11906 & 105248 \\
\hline LA & 1823 & 7001 & 8689 & 12647 & 6386 & 1454 & 18681 & 9061 & 10886 & 14841 & 91469 \\
\hline MA & 31854 & 7832 & 9516 & 11868 & 6808 & 1306 & 19079 & 14599 & 9197 & 26742 & 138802 \\
\hline MD & 35967 & 8750 & 8888 & 30163 & 6242 & 1173 & 16672 & 16432 & 21414 & 36463 & 182163 \\
\hline ME & 687 & 2245 & 1791 & 2411 & 1441 & 368 & 6088 & 3374 & 3021 & 5320 & 26745 \\
\hline MI & 4800 & 19346 & 7671 & 18251 & 14629 & 2153 & 34934 & 22151 & 9305 & 26283 & 159523 \\
\hline MN & 15465 & 10954 & 5093 & 17575 & 5673 & 1098 & 22985 & 12643 & 8643 & 25212 & 125342 \\
\hline MO & 9420 & 10121 & 9483 & 13197 & 8395 & 1705 & 27054 & 17497 & 8818 & 21226 & 126915 \\
\hline MS & 1613 & 3618 & 5153 & 6789 & 4423 & 587 & 12551 & 7999 & 17146 & 7447 & 67326 \\
\hline MT & 481 & 1313 & 1265 & 1602 & 1007 & 195 & 2723 & 1871 & 821 & 1533 & 12810 \\
\hline $\mathrm{NC}$ & 17294 & 14663 & 12678 & 36249 & 12044 & 2481 & 48139 & 36794 & 20559 & 37891 & 238792 \\
\hline ND & 76 & 1265 & 982 & 1490 & 1221 & 155 & 3567 & 1871 & 617 & 1077 & 12320 \\
\hline $\mathrm{NE}$ & 1586 & 4880 & 3263 & 6790 & 3562 & 577 & 12369 & 5533 & 3660 & 7279 & 49498 \\
\hline $\mathrm{NH}$ & 1523 & 2440 & 2437 & 2974 & 1653 & 548 & 6970 & 4421 & 2059 & 4717 & 29741 \\
\hline NJ & 30209 & 8563 & 10145 & 13295 & 8335 & 1210 & 26842 & 28280 & 32383 & 27841 & 187103 \\
\hline NM & 957 & 2655 & 4499 & 6636 & 3770 & 670 & 8235 & 8097 & 3142 & 5290 & 43950 \\
\hline $\mathrm{NV}$ & 30856 & 5684 & 31894 & 17504 & 12863 & 1691 & 25644 & 10337 & 17969 & 34776 & 189218 \\
\hline NY & 125095 & 17639 & 21083 & 35842 & 11572 & 2259 & 39107 & 24186 & 13845 & 36104 & 326732 \\
\hline $\mathrm{OH}$ & 6832 & 26393 & 9959 & 28780 & 13630 & 4004 & 55245 & 47919 & 36400 & 34909 & 264071 \\
\hline OK & 1242 & 8547 & 5511 & 8216 & 9450 & 1523 & 14686 & 12691 & 10032 & 13680 & 85577 \\
\hline OR & 13492 & 9885 & 3878 & 9927 & 4118 & 728 & 14881 & 7004 & 12291 & 17738 & 93941 \\
\hline PA & 16177 & 20535 & 15135 & 26096 & 14577 & 2361 & 40489 & 39397 & 37805 & 38280 & 250852 \\
\hline RI & 2559 & 649 & 2069 & 2707 & 877 & 278 & 2990 & 2125 & 1228 & 2540 & 18021 \\
\hline SC & 21321 & 8033 & 6056 & 16562 & 5801 & 1810 & 27984 & 23920 & 11848 & 22949 & 146284 \\
\hline SD & 142 & 1285 & 922 & 2767 & 1354 & 138 & 3668 & 2884 & 950 & 2202 & 16312 \\
\hline $\mathrm{TN}$ & 10621 & 11152 & 7347 & 24718 & 7891 & 2145 & 38548 & 19476 & 29045 & 25152 & 176095 \\
\hline TX & 59723 & 48519 & 38437 & 89641 & 35794 & 9142 & 141238 & 136629 & 114193 & 104156 & 777473 \\
\hline UT & 6695 & 6123 & 3384 & 14698 & 5110 & 822 & 15331 & 13657 & 13716 & 12926 & 92462 \\
\hline VA & 37694 & 10887 & 14646 & 39749 & 11794 & 2149 & 32438 & 25691 & 19659 & 47422 & 242129 \\
\hline VT & 1736 & 1063 & 1030 & 1214 & 765 & 68 & 674 & 1463 & 946 & 1777 & 10737 \\
\hline WA & 36566 & 11683 & 9378 & 26209 & 8964 & 1147 & 26954 & 19817 & 20236 & 38731 & 199685 \\
\hline WI & 9754 & 16350 & 6273 & 16751 & 8030 & 1474 & 26793 & 12148 & 9497 & 21325 & 128395 \\
\hline WV & 697 & 2314 & 1592 & 2081 & 1259 & 421 & 7191 & 5215 & 1930 & 3098 & 25797 \\
\hline WY & 42 & 774 & 1787 & 713 & 1370 & 97 & 1696 & 2737 & 718 & 2453 & 12387 \\
\hline Total & 1077585 & 517302 & 441399 & 991233 & 414953 & 82459 & 1384339 & 1015925 & 1063186 & 1277597 & 8265977 \\
\hline
\end{tabular}


Table A-4 New Commercial Building Construction Share by State and Building Type

\begin{tabular}{|c|c|c|c|c|c|c|c|c|c|c|c|c|}
\hline \multirow[b]{2}{*}{ State } & \multicolumn{12}{|c|}{ Percentage of Building Construction Volume } \\
\hline & Apartment & Healthcare & Hotel & Office & $\begin{array}{l}\text { Public } \\
\text { Assembly }\end{array}$ & Restaurant & Retail & School & Warehouse & $\begin{array}{l}\text { No } \\
\text { Prototype }\end{array}$ & Total & $\begin{array}{l}\text { Rep. by } \\
\text { Study }\end{array}$ \\
\hline AK & $1.3 \%$ & $9.0 \%$ & $8.7 \%$ & $15.6 \%$ & $7.6 \%$ & $0.9 \%$ & $14.4 \%$ & $15.9 \%$ & $8.7 \%$ & $17.9 \%$ & $100.0 \%$ & $56.8 \%$ \\
\hline $\mathrm{AL}$ & $7.1 \%$ & $6.3 \%$ & $7.6 \%$ & $13.3 \%$ & $5.7 \%$ & $1.5 \%$ & $22.0 \%$ & $13.6 \%$ & $7.5 \%$ & $15.4 \%$ & $100.0 \%$ & $65.2 \%$ \\
\hline AR & $2.0 \%$ & $7.8 \%$ & $8.1 \%$ & $10.9 \%$ & $5.7 \%$ & $1.3 \%$ & $22.9 \%$ & $21.8 \%$ & $5.7 \%$ & $13.7 \%$ & $100.0 \%$ & $67.1 \%$ \\
\hline $\mathrm{AZ}$ & $4.4 \%$ & $6.3 \%$ & $4.4 \%$ & $16.9 \%$ & $5.0 \%$ & $1.1 \%$ & $20.6 \%$ & $9.6 \%$ & $15.6 \%$ & $16.0 \%$ & $100.0 \%$ & $57.1 \%$ \\
\hline CA & $13.5 \%$ & $4.6 \%$ & $4.3 \%$ & $12.7 \%$ & $4.3 \%$ & $0.7 \%$ & $14.7 \%$ & $9.8 \%$ & $18.4 \%$ & $17.0 \%$ & $100.0 \%$ & $55.7 \%$ \\
\hline $\mathrm{CO}$ & $12.4 \%$ & $8.4 \%$ & $6.1 \%$ & $13.1 \%$ & $4.3 \%$ & $1.2 \%$ & $17.6 \%$ & $10.0 \%$ & $9.4 \%$ & $17.5 \%$ & $100.0 \%$ & $60.4 \%$ \\
\hline CT & $8.5 \%$ & $5.6 \%$ & $6.8 \%$ & $8.6 \%$ & $7.1 \%$ & $0.9 \%$ & $17.2 \%$ & $16.5 \%$ & $11.3 \%$ & $17.6 \%$ & $100.0 \%$ & $58.5 \%$ \\
\hline DC & $28.7 \%$ & $1.7 \%$ & $2.7 \%$ & $35.7 \%$ & $2.7 \%$ & $0.1 \%$ & $2.5 \%$ & $4.7 \%$ & $0.8 \%$ & $20.3 \%$ & $100.0 \%$ & $74.4 \%$ \\
\hline $\mathrm{DE}$ & $4.1 \%$ & $9.0 \%$ & $7.2 \%$ & $13.0 \%$ & $6.9 \%$ & $0.9 \%$ & $13.8 \%$ & $16.9 \%$ & $9.3 \%$ & $18.8 \%$ & $100.0 \%$ & $55.9 \%$ \\
\hline FL & $25.9 \%$ & $4.1 \%$ & $3.6 \%$ & $10.9 \%$ & $3.8 \%$ & $0.8 \%$ & $14.4 \%$ & $9.4 \%$ & $11.7 \%$ & $15.4 \%$ & $100.0 \%$ & $65.0 \%$ \\
\hline GA & $10.2 \%$ & $4.3 \%$ & $4.2 \%$ & $10.0 \%$ & $3.3 \%$ & $0.9 \%$ & $16.3 \%$ & $15.4 \%$ & $20.6 \%$ & $14.8 \%$ & $100.0 \%$ & $57.0 \%$ \\
\hline $\mathrm{HI}$ & $47.7 \%$ & $3.4 \%$ & $3.4 \%$ & $6.4 \%$ & $2.2 \%$ & $0.3 \%$ & $10.2 \%$ & $3.4 \%$ & $4.9 \%$ & $18.1 \%$ & $100.0 \%$ & $71.4 \%$ \\
\hline IA & $2.0 \%$ & $8.8 \%$ & $5.9 \%$ & $13.8 \%$ & $9.1 \%$ & $1.0 \%$ & $18.7 \%$ & $17.4 \%$ & $8.6 \%$ & $14.7 \%$ & $100.0 \%$ & $58.8 \%$ \\
\hline ID & $5.8 \%$ & $9.3 \%$ & $5.5 \%$ & $17.9 \%$ & $5.7 \%$ & $1.1 \%$ & $17.4 \%$ & $15.9 \%$ & $9.0 \%$ & $12.4 \%$ & $100.0 \%$ & $63.6 \%$ \\
\hline IL & $21.1 \%$ & $5.1 \%$ & $3.8 \%$ & $8.5 \%$ & $4.9 \%$ & $0.7 \%$ & $16.3 \%$ & $8.9 \%$ & $18.7 \%$ & $12.1 \%$ & $100.0 \%$ & $59.2 \%$ \\
\hline IN & $2.0 \%$ & $9.4 \%$ & $4.7 \%$ & $9.5 \%$ & $7.2 \%$ & $1.4 \%$ & $18.0 \%$ & $14.0 \%$ & $20.6 \%$ & $13.2 \%$ & $100.0 \%$ & $49.6 \%$ \\
\hline KS & $1.8 \%$ & $9.9 \%$ & $6.5 \%$ & $16.3 \%$ & $5.5 \%$ & $1.8 \%$ & $20.8 \%$ & $15.3 \%$ & $9.5 \%$ & $12.5 \%$ & $100.0 \%$ & $62.6 \%$ \\
\hline KY & $2.7 \%$ & $7.7 \%$ & $6.6 \%$ & $11.9 \%$ & $7.8 \%$ & $1.4 \%$ & $17.0 \%$ & $13.0 \%$ & $20.5 \%$ & $11.3 \%$ & $100.0 \%$ & $52.7 \%$ \\
\hline LA & $2.0 \%$ & $7.7 \%$ & $9.5 \%$ & $13.8 \%$ & $7.0 \%$ & $1.6 \%$ & $20.4 \%$ & $9.9 \%$ & $11.9 \%$ & $16.2 \%$ & $100.0 \%$ & $57.2 \%$ \\
\hline MA & $22.9 \%$ & $5.6 \%$ & $6.9 \%$ & $8.6 \%$ & $4.9 \%$ & $0.9 \%$ & $13.7 \%$ & $10.5 \%$ & $6.6 \%$ & $19.3 \%$ & $100.0 \%$ & $63.6 \%$ \\
\hline MD & $19.7 \%$ & $4.8 \%$ & $4.9 \%$ & $16.6 \%$ & $3.4 \%$ & $0.6 \%$ & $9.2 \%$ & $9.0 \%$ & $11.8 \%$ & $20.0 \%$ & $100.0 \%$ & $60.0 \%$ \\
\hline ME & $2.6 \%$ & $8.4 \%$ & $6.7 \%$ & $9.0 \%$ & $5.4 \%$ & $1.4 \%$ & $22.8 \%$ & $12.6 \%$ & $11.3 \%$ & $19.9 \%$ & $100.0 \%$ & $55.0 \%$ \\
\hline MI & $3.0 \%$ & $12.1 \%$ & $4.8 \%$ & $11.4 \%$ & $9.2 \%$ & $1.3 \%$ & $21.9 \%$ & $13.9 \%$ & $5.8 \%$ & $16.5 \%$ & $100.0 \%$ & $56.4 \%$ \\
\hline $\mathrm{MN}$ & $12.3 \%$ & $8.7 \%$ & $4.1 \%$ & $14.0 \%$ & $4.5 \%$ & $0.9 \%$ & $18.3 \%$ & $10.1 \%$ & $6.9 \%$ & $20.1 \%$ & $100.0 \%$ & $59.7 \%$ \\
\hline $\mathrm{MO}$ & $7.4 \%$ & $8.0 \%$ & $7.5 \%$ & $10.4 \%$ & $6.6 \%$ & $1.3 \%$ & $21.3 \%$ & $13.8 \%$ & $6.9 \%$ & $16.7 \%$ & $100.0 \%$ & $61.7 \%$ \\
\hline MS & $2.4 \%$ & $5.4 \%$ & $7.7 \%$ & $10.1 \%$ & $6.6 \%$ & $0.9 \%$ & $18.6 \%$ & $11.9 \%$ & $25.5 \%$ & $11.1 \%$ & $100.0 \%$ & $51.5 \%$ \\
\hline MT & $3.8 \%$ & $10.2 \%$ & $9.9 \%$ & $12.5 \%$ & $7.9 \%$ & $1.5 \%$ & $21.3 \%$ & $14.6 \%$ & $6.4 \%$ & $12.0 \%$ & $100.0 \%$ & $63.5 \%$ \\
\hline $\mathrm{NC}$ & $7.2 \%$ & $6.1 \%$ & $5.3 \%$ & $15.2 \%$ & $5.0 \%$ & $1.0 \%$ & $20.2 \%$ & $15.4 \%$ & $8.6 \%$ & $15.9 \%$ & $100.0 \%$ & $64.3 \%$ \\
\hline ND & $0.6 \%$ & $10.3 \%$ & $8.0 \%$ & $12.1 \%$ & $9.9 \%$ & $1.3 \%$ & $29.0 \%$ & $15.2 \%$ & $5.0 \%$ & $8.7 \%$ & $100.0 \%$ & $66.1 \%$ \\
\hline $\mathrm{NE}$ & $3.2 \%$ & $9.9 \%$ & $6.6 \%$ & $13.7 \%$ & $7.2 \%$ & $1.2 \%$ & $25.0 \%$ & $11.2 \%$ & $7.4 \%$ & $14.7 \%$ & $100.0 \%$ & $60.8 \%$ \\
\hline $\mathrm{NH}$ & $5.1 \%$ & $8.2 \%$ & $8.2 \%$ & $10.0 \%$ & $5.6 \%$ & $1.8 \%$ & $23.4 \%$ & $14.9 \%$ & $6.9 \%$ & $15.9 \%$ & $100.0 \%$ & $63.5 \%$ \\
\hline $\mathrm{NJ}$ & $16.1 \%$ & $4.6 \%$ & $5.4 \%$ & $7.1 \%$ & $4.5 \%$ & $0.6 \%$ & $14.3 \%$ & $15.1 \%$ & $17.3 \%$ & $14.9 \%$ & $100.0 \%$ & $58.8 \%$ \\
\hline NM & $2.2 \%$ & $6.0 \%$ & $10.2 \%$ & $15.1 \%$ & $8.6 \%$ & $1.5 \%$ & $18.7 \%$ & $18.4 \%$ & $7.1 \%$ & $12.0 \%$ & $100.0 \%$ & $66.2 \%$ \\
\hline NV & $16.3 \%$ & $3.0 \%$ & $16.9 \%$ & $9.3 \%$ & $6.8 \%$ & $0.9 \%$ & $13.6 \%$ & $5.5 \%$ & $9.5 \%$ & $18.4 \%$ & $100.0 \%$ & $62.3 \%$ \\
\hline NY & $38.3 \%$ & $5.4 \%$ & $6.5 \%$ & $11.0 \%$ & $3.5 \%$ & $0.7 \%$ & $12.0 \%$ & $7.4 \%$ & $4.2 \%$ & $11.1 \%$ & $100.0 \%$ & $75.8 \%$ \\
\hline $\mathrm{OH}$ & $2.6 \%$ & $10.0 \%$ & $3.8 \%$ & $10.9 \%$ & $5.2 \%$ & $1.5 \%$ & $20.9 \%$ & $18.1 \%$ & $13.8 \%$ & $13.2 \%$ & $100.0 \%$ & $57.8 \%$ \\
\hline OK & $1.5 \%$ & $10.0 \%$ & $6.4 \%$ & $9.6 \%$ & $11.0 \%$ & $1.8 \%$ & $17.2 \%$ & $14.8 \%$ & $11.7 \%$ & $16.0 \%$ & $100.0 \%$ & $51.3 \%$ \\
\hline OR & $14.4 \%$ & $10.5 \%$ & $4.1 \%$ & $10.6 \%$ & $4.4 \%$ & $0.8 \%$ & $15.8 \%$ & $7.5 \%$ & $13.1 \%$ & $18.9 \%$ & $100.0 \%$ & $53.1 \%$ \\
\hline PA & $6.4 \%$ & $8.2 \%$ & $6.0 \%$ & $10.4 \%$ & $5.8 \%$ & $0.9 \%$ & $16.1 \%$ & $15.7 \%$ & $15.1 \%$ & $15.3 \%$ & $100.0 \%$ & $55.7 \%$ \\
\hline RI & $14.2 \%$ & $3.6 \%$ & $11.5 \%$ & $15.0 \%$ & $4.9 \%$ & $1.5 \%$ & $16.6 \%$ & $11.8 \%$ & $6.8 \%$ & $14.1 \%$ & $100.0 \%$ & $70.6 \%$ \\
\hline $\mathrm{SC}$ & $14.6 \%$ & $5.5 \%$ & $4.1 \%$ & $11.3 \%$ & $4.0 \%$ & $1.2 \%$ & $19.1 \%$ & $16.4 \%$ & $8.1 \%$ & $15.7 \%$ & $100.0 \%$ & $66.8 \%$ \\
\hline SD & $0.9 \%$ & $7.9 \%$ & $5.7 \%$ & $17.0 \%$ & $8.3 \%$ & $0.8 \%$ & $22.5 \%$ & $17.7 \%$ & $5.8 \%$ & $13.5 \%$ & $100.0 \%$ & $64.5 \%$ \\
\hline $\mathrm{TN}$ & $6.0 \%$ & $6.3 \%$ & $4.2 \%$ & $14.0 \%$ & $4.5 \%$ & $1.2 \%$ & $21.9 \%$ & $11.1 \%$ & $16.5 \%$ & $14.3 \%$ & $100.0 \%$ & $58.4 \%$ \\
\hline TX & $7.7 \%$ & $6.2 \%$ & $4.9 \%$ & $11.5 \%$ & $4.6 \%$ & $1.2 \%$ & $18.2 \%$ & $17.6 \%$ & $14.7 \%$ & $13.4 \%$ & $100.0 \%$ & $61.1 \%$ \\
\hline UT & $7.2 \%$ & $6.6 \%$ & $3.7 \%$ & $15.9 \%$ & $5.5 \%$ & $0.9 \%$ & $16.6 \%$ & $14.8 \%$ & $14.8 \%$ & $14.0 \%$ & $100.0 \%$ & $59.0 \%$ \\
\hline VA & $15.6 \%$ & $4.5 \%$ & $6.0 \%$ & $16.4 \%$ & $4.9 \%$ & $0.9 \%$ & $13.4 \%$ & $10.6 \%$ & $8.1 \%$ & $19.6 \%$ & $100.0 \%$ & $62.9 \%$ \\
\hline VT & $16.2 \%$ & $9.9 \%$ & $9.6 \%$ & $11.3 \%$ & $7.1 \%$ & $0.6 \%$ & $6.3 \%$ & $13.6 \%$ & $8.8 \%$ & $16.6 \%$ & $100.0 \%$ & $57.6 \%$ \\
\hline WA & $18.3 \%$ & $5.9 \%$ & $4.7 \%$ & $13.1 \%$ & $4.5 \%$ & $0.6 \%$ & $13.5 \%$ & $9.9 \%$ & $10.1 \%$ & $19.4 \%$ & $100.0 \%$ & $60.1 \%$ \\
\hline WI & $7.6 \%$ & $12.7 \%$ & $4.9 \%$ & $13.0 \%$ & $6.3 \%$ & $1.1 \%$ & $20.9 \%$ & $9.5 \%$ & $7.4 \%$ & $16.6 \%$ & $100.0 \%$ & $57.0 \%$ \\
\hline WV & $2.7 \%$ & $9.0 \%$ & $6.2 \%$ & $8.1 \%$ & $4.9 \%$ & $1.6 \%$ & $27.9 \%$ & $20.2 \%$ & $7.5 \%$ & $12.0 \%$ & $100.0 \%$ & $66.7 \%$ \\
\hline WY & $0.3 \%$ & $6.2 \%$ & $14.4 \%$ & $5.8 \%$ & $11.1 \%$ & $0.8 \%$ & $13.7 \%$ & $22.1 \%$ & $5.8 \%$ & $19.8 \%$ & $100.0 \%$ & $57.1 \%$ \\
\hline Total & $13.0 \%$ & $6.3 \%$ & $5.3 \%$ & $12.0 \%$ & $5.0 \%$ & $1.0 \%$ & $16.7 \%$ & $12.3 \%$ & $12.9 \%$ & $15.5 \%$ & $100.0 \%$ & $60.4 \%$ \\
\hline
\end{tabular}


Table A-5 Energy Consumption Savings by State

\begin{tabular}{|c|c|c|c|}
\hline State & Code & $\begin{array}{c}\text { Average Annual New } \\
\text { Floor Area } \\
1000 \mathbf{~ m}^{2}\left(1000 \mathrm{ft}^{2}\right)\end{array}$ & $\begin{array}{c}\text { Energy Use } \\
\text { (GWh) }\end{array}$ \\
\hline FL & 2007 & $16542(178061)$ & 3790.5 \\
\hline $\mathrm{TX}$ & 2007 & $14446(155495)$ & 2831.6 \\
\hline CA & 2007 & $14492(155996)$ & 2543.2 \\
\hline $\mathrm{AZ}$ & 1999 & $4758(51214)$ & 1857.5 \\
\hline GA & 2007 & $7240(77934)$ & 1348.0 \\
\hline IL & 2007 & $6929(74579)$ & 1212.7 \\
\hline $\mathrm{CO}$ & 2001 & $3292(35437)$ & 1112.9 \\
\hline $\mathrm{AL}$ & 1999 & $2254(24266)$ & 1050.6 \\
\hline NY & 2007 & $6071(65346)$ & 1037.6 \\
\hline MO & None & $2358(25383)$ & 984.7 \\
\hline VA & 2007 & $4499(48426)$ & 871.3 \\
\hline $\mathrm{NC}$ & 2007 & 4437 (47 758) & 827.9 \\
\hline $\mathrm{OH}$ & 2007 & 4907 (52 814) & 826.8 \\
\hline $\mathrm{MN}$ & 2004 & $2329(25068)$ & 816.7 \\
\hline $\mathrm{TN}$ & 2004 & 3272 (35 219) & 807.8 \\
\hline PA & 2007 & $4661(50170)$ & 764.9 \\
\hline NV & 2004 & $3516(37844)$ & 709.0 \\
\hline MS & 1999 & $1251(13465)$ & 689.6 \\
\hline IN & 2007 & $3663(39425)$ & 656.9 \\
\hline MD & 2007 & 3385 (36 433) & 622.2 \\
\hline $\mathrm{OK}$ & 1999 & $1590(17$ 115) & 598.1 \\
\hline $\mathrm{SC}$ & 2004 & 2718 (29 257) & 594.5 \\
\hline $\mathrm{NJ}$ & 2007 & $3476(37421)$ & 581.6 \\
\hline WA & 2007 & 3710 (39 937) & 525.0 \\
\hline MI & 2007 & $2964(31905)$ & 511.9 \\
\hline
\end{tabular}

\begin{tabular}{|c|c|c|c|}
\hline State & Code & $\begin{array}{c}\text { Average Annual New } \\
\text { Floor Area } \\
1000 \mathbf{~ m}^{2}\left(1000 \mathrm{ft}^{2}\right)\end{array}$ & $\begin{array}{c}\text { Energy Use } \\
\text { (GWh) }\end{array}$ \\
\hline WI & 2007 & $2386(25679)$ & 491.0 \\
\hline KS & None & 1077 (11 590) & 438.6 \\
\hline AR & 2001 & $1186(12762)$ & 426.1 \\
\hline MA & 2007 & $2579(27760)$ & 403.8 \\
\hline KY & 2007 & $1956(21050)$ & 378.0 \\
\hline LA & 2007 & $1700(18294)$ & 324.6 \\
\hline UT & 2007 & $1718(18$ 492) & 286.6 \\
\hline IA & 2007 & 1447 (15 573) & 283.7 \\
\hline OR & 2007 & $1745(18788)$ & 261.4 \\
\hline $\mathrm{CT}$ & 2007 & $1445(15549)$ & 232.0 \\
\hline $\mathrm{ME}$ & None & $497(5349)$ & 216.6 \\
\hline WV & 2001 & 479 (5159) & 177.2 \\
\hline $\mathrm{NE}$ & 2007 & $920(9900)$ & 170.8 \\
\hline NM & 2007 & 817 (8790) & 153.7 \\
\hline ID & 2007 & 802 (8629) & 139.9 \\
\hline $\mathrm{HI}$ & 2004 & $536(5773)$ & 138.4 \\
\hline SD & None & $303(3262)$ & 122.3 \\
\hline $\mathrm{NH}$ & 2007 & $553(5948)$ & 108.0 \\
\hline ND & None & $229(2464)$ & 104.5 \\
\hline $\mathrm{AK}$ & 1999 & $290(3116)$ & 99.4 \\
\hline WY & 1999 & $230(2477)$ & 76.6 \\
\hline $\mathrm{DE}$ & 2007 & $344(3700)$ & 60.1 \\
\hline RI & 2007 & $335(3604)$ & 55.3 \\
\hline MT & 2007 & $238(2562)$ & 52.5 \\
\hline VT & 2007 & $200(2147)$ & 37.3 \\
\hline
\end{tabular}

